NBER WORKING PAPER SERIES

\title{
CAN NATURAL GAS SAVE LIVES? EVIDENCE FROM THE DEPLOYMENT OF A FUEL DELIVERY SYSTEM IN A DEVELOPING COUNTRY
}

\author{
Resul Cesur \\ Erdal Tekin \\ Aydogan Ulker \\ Working Paper 22522 \\ http://www.nber.org/papers/w22522 \\ NATIONAL BUREAU OF ECONOMIC RESEARCH \\ 1050 Massachusetts Avenue \\ Cambridge, MA 02138 \\ August 2016
}

Erdal Tekin gratefully acknowledges support from the Gary and Stacey Jacobs Fellowship. The views expressed herein are those of the authors and do not necessarily reflect the views of the National Bureau of Economic Research.

NBER working papers are circulated for discussion and comment purposes. They have not been peer-reviewed or been subject to the review by the NBER Board of Directors that accompanies official NBER publications.

(C) 2016 by Resul Cesur, Erdal Tekin, and Aydogan Ulker. All rights reserved. Short sections of text, not to exceed two paragraphs, may be quoted without explicit permission provided that full credit, including $\odot$ notice, is given to the source. 
Can Natural Gas Save Lives? Evidence from the Deployment of a Fuel Delivery System in

a Developing Country

Resul Cesur, Erdal Tekin, and Aydogan Ulker

NBER Working Paper No. 22522

August 2016

JEL No. I10,I15,I18,O13,O18,Q42,Q48,Q53

\begin{abstract}
There has been a widespread displacement of coal by natural gas as space heating and cooking technology in Turkey in the last two decades, triggered by the deployment of natural gas networks. In this paper, we examine the impact of this development on mortality among adults and the elderly. Our research design exploits the variation in the timing of the deployment and the intensity of expansion of natural gas networks at the provincial level using data from 2001 to 2014. The results indicate that the expansion of natural gas services has caused significant reductions in both the adult and the elderly mortality rates. According to our point estimates, a one-percentage point increase in the rate of subscriptions to natural gas services would lower the overall mortality rate by 1.4 percent, the adult mortality rate by 1.9 percent, and the elderly mortality rate by 1.2 percent. These findings are supported by our auxiliary analysis, which demonstrates that the expansion of natural gas networks has indeed led to a significant improvement in air quality. Furthermore, we show that the mortality gains for both the adult and the elderly populations are primarily driven by reductions in cardio-respiratory deaths, which are more likely to be due to conditions caused or exacerbated by air pollution. Finally, our analysis does not reveal any important gender differences in the estimated relationship between the deployment of natural gas networks and mortality.
\end{abstract}

Resul Cesur

Department of Finance

University of Connecticut

2100 Hillside Road Unit 1041

Storrs, CT 06269-1041

cesur@business.uconn.edu

Erdal Tekin

School of Public Affairs

American University

4400 Massachusetts Avenue NW

Washington, DC 20016-8070

and IZA

and also NBER

tekin@american.edu
Aydogan Ulker

Department of Economics

Deakin University

221 Burwood Highway

Burwood VIC, 3125

Australia

ulker@deakin.edu.au 


\section{Introduction}

The recent emergence of natural gas as an abundant, efficient, and relatively inexpensive source of fuel has been transforming the world energy landscape. The new discoveries of large gas fields and technological innovations in drilling, such as hydraulic fracturing (aka fracking), are unlocking massive reserves of natural gas and threatening the position of coal as the dominant source of energy in many parts of the world. Natural gas is now the fastest-growing fossil fuel, with an annual growth rate of 1.9 percent, while coal is the slowest-growing fuel and is projected to be surpassed by natural gas by 2030 (U.S. Energy Information Administration, 2016). As a result of these developments, the average carbon intensity $\left(\mathrm{CO}_{2}\right.$ per unit of energy) of the global energy supply has started to decline as $\mathrm{CO}_{2}$ emissions from the combustion of natural gas are about half as much as those from the burning of coal. ${ }^{1}$ In fact, the combustion of natural gas results in much lower emissions of nearly all types of pollutants (Knittel et al., 2015). ${ }^{2}$ Furthermore, natural gas requires limited processing to prepare it for end use, which makes it ideal for the purposes of domestic and commercial space heating. As a result of these qualities, some experts view the ongoing replacement of coal by natural gas as a positive development, which could be leveraged as a common sense approach to address the problem of global carbon emissions in the near- to mid-term, even if it cannot be the sole basis for efforts to achieving a completely renewable future long-term energy landscape (Brown et al., 2009; Center for Climate and Energy Solutions, 2013; Levi, 2013; Moniz et al., 2011).

\footnotetext{
${ }^{1}$ It is important to note that total $\mathrm{CO}_{2}$ emissions continue to rise despite the decrease in carbon intensity. But it is projected that the share of coal in overall fuel consumption would fall from 28 percent in 2012 to 22 percent in 2040, while that of natural gas would rise from 23 percent to 26 percent (U.S. Energy Information Administration, 2016).

${ }^{2}$ For example, natural gas virtually emits no sulfur oxides and particulates, and it releases about one-fifth of the nitrogen oxides released by coal. See http://www.c2es.org/energy/source/natural-gas.
} 
While many developed countries have enacted environmental policies and regulations, and established effective monitoring systems to reduce carbon emissions, the progress in the developing world has been relatively stagnant because there are barriers to effective enforcement of regulations due to weak governance and corruption (Cesur et al., 2016; Greenstone and Hanna, 2014; Jayachandran, 2009). Environmental concerns are also overshadowed by the pressure that governments in these countries are facing in order to maintain robust economic growth. As a result, heavy reliance on coal continues and a full-scale transition to cost-effective, carbon-free energy alternatives are unlikely to develop in the near-term. Therefore, the potential for natural gas to mitigate climate change and reduce air pollution could particularly be a promising prospect for the developing countries.

Against this backdrop, an important question to consider is whether a technological development that led to a displacement of coal by natural gas would have an influence on public health. If natural gas indeed possesses the aforementioned qualities, then it is plausible to ask whether policies facilitating the expansion of natural gas infrastructure for commercial and residential applications translate into subsequent improvements in public health. This is a critically important question because ambient air pollution caused by carbon emissions is recognized as the most serious environmental risk to public health causing 3.7 million deaths worldwide -6.7 percent of all deaths - annually. ${ }^{3}$ It is estimated that about 16 percent of the lung cancer deaths, 11 percent of chronic obstructive pulmonary disease deaths, more than 20 percent of ischemic heart disease and stroke deaths, and about 13 percent of respiratory infection deaths are caused by air pollution. Therefore, it is important to understand whether the expanded use of natural gas as a replacement to coal could save some of these lives, at least until carbon-

\footnotetext{
${ }^{3}$ See http://www.who.int/gho/phe/outdoor_air_pollution/burden_text/en/.
} 
free energy alternatives become widely available. This paper seeks to inform this question by assessing the impact of a large scale deployment of natural gas networks on public health in the context of a developing country, namely Turkey. Turkey has begun investing in the development of a natural gas infrastructure in 1980s by expanding a grid of pipelines originating in its neighbours, including Azerbaijan, Iran, and Russia. These investments have led to a widespread displacement of coal by natural gas for residential and commercial space heating and cooking purposes. Today, 71 of the 81 Turkish provinces has a natural gas infrastructure in place. By exploiting the variation in the deployment of natural gas networks across Turkish provinces and over time, this study provides insights into the impact of displacement of coal by natural gas on adult and elderly mortality.

Despite all the attention paid to the natural gas revolution and its potentially profound implications for air pollution, the influence of a nationwide adoption of natural gas as the primary source of fuel on public health, particularly from the perspective of adults and the elderly is largely unknown. The only other investigation on this topic, Cesur et al. (2016), demonstrates that a widespread displacement of coal by natural gas had a significant reduction in infant mortality in Turkey. In the present study, we take the analysis in Cesur et al. (2016) a step further by examining the efficacy of the deployment of natural gas networks on mortality rates among adults and the elderly. This analysis is important because the potential role for governments to enhance social welfare by either funding the construction of pipelines or inducing household demand via subsidies requires a cost-benefit analysis that quantifies the public health benefits associated with displacing coal by natural gas for all age groups, not only infants. In this paper, we also assess whether any of the relationship between natural gas and mortality is gender or cause specific. There is epidemiological evidence to suggest that the health 
risks posed by air pollution might differ by gender (e.g., Abbey et al.,1999; Chen et al., 2012; Clougherty, 2010; Dockery et al., 1993; Englert, 2004). Studies typically find effects that are stronger for females than males, although there is no consensus in the literature. It is also unclear to what extent these differing associations are attributable to socially-driven gender-specific differences (e.g., activity patterns, smoking prevalence, and exposure) versus biological differences (e.g., hormonal composition, reproductive organs, body size) (Clougherty, 2010; Krieger, 2003).

This paper also contributes to a small but growing literature on the impact of fuel transitions and adoption of new fuel technologies. Most of the existing evidence pertaining to the effects of natural gas related technology adoption comes from studies that consider the potential impact of fracking on public health outcomes of populations living near drilling sites (e.g., Adgate et al., 2014; Blamberger and Oswald, 2012; Colborn et al., 2012; Finkel and Hays, 2015; Finkel and Law, 2011; Hill, 2012; Howarth et al., 2011; Osborn et al., 2011; Tuller, 2015). ${ }^{4}$ However, this effect is likely to be quite different from that of the displacement of coal by natural gas. First and foremost, studies on fracking raise concerns over the technique of extraction of natural gas and not over the choice between the combustion of natural gas versus coal. To the extent that any fracking-induced decrease in the price of natural gas might potentially cause a reduction in coal consumption and concurrently improve overall air quality, the net health effect associated with fracking could actually be positive. Until these positive externalities are fully considered, the debate over the net merit of fracking will not be settled. Second, natural gas considered in the current context does not pose the same environmental risks

\footnotetext{
${ }^{4}$ Evidence from these studies raise the possibility of a potentially negative health impact of fracking in relation to the chemicals used during the process, including seismic events, methane leaks, and underground water contamination. However, no consensus exists in the literature and there is a lack of credible evidence from welldesigned investigations that properly account for confounding factors.
} 
as in fracking because it is transmitted through pipelines that originate in wells located outside Turkey and drilled by the conventional vertical technique, which has a much smaller carbon print.

One exception to the fracking studies that is also relevant for the present paper is a recent analysis by Barreca et al. (2014), who examine the effects of bituminous coal consumption for home heating on infant and all age mortality rates in the United States during the mid-twentieth century. The authors show that the reductions in the consumption of coal between 1945 and 1960 significantly decreased both infant and all age mortality. The time frame considered in their analysis was also a period that coincides with a rapid switch away from coal towards oil and natural gas. This is important in terms of illustrating the potential role that a widespread displacement of coal by cleaner sources of fuel might have played on public health in the United States. ${ }^{5}$ While the United States and many developed countries have made inroads towards cleaner fuels, the developing world continues to rely primarily on coal to meet its energy requirements. ${ }^{6}$ We believe that it is important to identify and highlight the impact of socially desirable and economically viable public and market based approaches that would help natural gas gain traction as an alternative to coal in developing countries.

This papers also extends the literature on the impact of air pollution on the health outcomes of adults and the elderly. Research in economics and epidemiology has shown that exposure to air pollution has adverse effects on health by causing conditions such as pulmonary

\footnotetext{
${ }^{5}$ In particular, while the share of coal as a fuel for heating purposes declined from 55 to 35 percent, the share of natural gas increased by over 400 percent (see page 10 in Barreca et al., 2014).

${ }^{6}$ See for example, http://instituteforenergyresearch.org/analysis/coal-is-still-integral-to-many-countries-and-regionsin-the-world/.
} 
and systemic inflammation, accelerated atherosclerosis, heart arrhythmias, and pneumonia. ${ }^{7}$ One of the most notable contribution of economists in this field has been the improvement of empirical strategies to obtain causal estimates of the impact of exposure to air pollution, which is arguably endogenous. To highlight a few recent and notable examples, Chen et al. (2013) exploit the Huai River policy experiment in China to examine the impact of long-term exposure to air pollution on adult mortality. The authors first demonstrate that the policy, which provided free coal to citizens living to the north of the Huai River but not to the south, caused a substantial rise in total particulate matter (TSP) in the north relative to the south. They then show that the increase in TSP was accompanied with a significant increase in adult mortality in the affected regions due to the elevated rates of cardio-respiratory deaths. Anderson (2015) examines the impact of long-term exposure to air pollution on mortality by exploiting quasi-random variation in pollution levels generated by wind patterns near major highways in Los Angeles. He finds statistically and economically significant effects of downwind exposure to near-roadway pollution on mortality amongst the elderly. Finally, Schlenker and Walker (2015) exploit the variation in air pollution caused by runway traffic congestion in California airports to show that increased pollution levels in areas surrounding airports are associated with asthma, respiratory, and heart related hospitalizations among infants, adults, and elderly population. ${ }^{8}$ It is important to note that all these three papers provide estimates for the health impact of a rise in air pollution, while the current paper considers the health effect of a development that results in a decrease in air pollution. This distinction is important because the relationship between air pollution and

\footnotetext{
${ }^{7}$ For example, see Anderson (2015), Barreca et al. (2014), Chen et al. (2013), DelFino et al. (2005), Dockery et al., 1993; Lockwood (2012), Pope et al. (2004), and Schlenker and Walker (2015).

${ }^{8}$ Both Chen et al. (2013) and Anderson (2015) focus on the health impact of long-term exposure to air pollution, Schlenker and Walker (2015) consider day-to-day fluctuations, which results in estimates for the short-run effect of air pollution on health rather than the long-run cumulative impact.
} 
mortality needs not be symmetrical. This is especially likely to be true for an outcome like mortality that is irreversible. Furthermore, health problems caused by air pollution usually become chronic (e.g., heart and lung disease) and chronic conditions are not easily reversible when air quality is improved. Additionally, any health benefits attributable to improved air quality may be felt over time rather than being realized immediately, especially for adults and the elderly for whom most deaths are likely due to chronic conditions. In this paper, we recognize this issue by specifying a treatment variable that captures a dose-effect relationship rather a binary treatment approach adopted in most of the extant literature.

The research design in our study exploits the variation in the intensity of natural gas consumption, as measured by the number of subscribers to natural gas services per 100 persons, across Turkish provinces and over time. Our results indicate that the displacement of coal by natural gas induced by the deployment of natural gas networks has resulted in a significant improvement in air quality, which then caused mortality rate among adults and the elderly to decrease significantly. According to our point estimates, a one-percentage point increase in the intensity of natural gas consumption results in 1.9 and 1.2 percent decrease in the rates of mortality among adults and the elderly, respectively. Furthermore, these mortality gains appear to be almost exclusively driven by decreases in deaths due to cardio-respiratory conditions. This is not surprising since adult and elderly deaths are closely related to chronic disease conditions, which are likely to be exacerbated by air pollution. Finally, we find no evidence of meaningful differential effects between males and females.

\section{Background}


The developments that have led to the deployment of a natural gas infrastructure in Turkey have been discussed in detail in Cesur et al. (2016). Essentially, the rationale behind the country's decision to make massive investments on a network of natural gas pipelines was to diversify its energy portfolio and thereby reduce its vulnerability to global supply shortages in oil. Natural gas was identified as the most economically and technologically feasible candidate to add to its energy mix, given Turkey’s close proximity to some of the world’s largest natural gas producers such as Azerbaijan, Iran, and Russia. Importantly for the purpose of the present study, there is no evidence that improving public health was among the factors that played a role in the decision to deploy natural gas networks. First deployed in Ankara in 1988, natural gas networks spread gradually across Turkey over time and reached to 71 of the 81 provinces by 2014. Natural gas is imported from Azerbaijan, Iran, and Russia through pipelines that are operated by a state owned company called Botas. ${ }^{9}$ The gas is then transmitted to individual provinces by privately owned distribution companies that are responsible for providing the public with clean burning natural gas by establishing and operating all infrastructural facilities for the utilization of natural gas. ${ }^{10}$

The deployment of natural gas networks has led to a rapid increase in the consumption of natural gas for domestic heating and cooking purposes, while the pace of increase in coal consumption has been much slower. For example, between the years of 2000 and 2010, the total consumption of coal and peat increased from 11 million tons of oil equivalent (Mtoe) to 14

\footnotetext{
${ }^{9}$ Over 60 percent of the natural gas used in Turkey is exported from Russia, which arrives in Turkey via two routes, first one coming through the Blue Stream pipeline that crosses the Black Sea and the other one traveling via the West Gas Pipeline through Bulgaria. The capacity of these two pipelines is about 30 billion cubic meters (bcm). Another pipeline with a capacity of $8.8 \mathrm{bcm}$ is with Azerbaijan that travels through Georgia via the Baku-TbilisiErzurum pipeline that was launched in 2007. The third connection is to Iran with a capacity of $10 \mathrm{bcm}$ of natural gas. About 79 percent of natural gas imports are transmitted through pipelines, while the remaining 21 percent comes in liquefied form, mainly from Azerbaijan, Algeria, and Nigeria (International Energy Agency, 2011).

${ }^{10}$ For example, the companies in charge of distribution in the three largest provinces, Istanbul, Ankara, and Izmir are Igdas, Baskentgaz, and Izmirgaz, respectively.
} 
Mtoe, while the natural gas consumption has nearly tripled from 4.9 Mtoe to 13.1 Mtoe. During the same period, the share of natural gas in electricity production increased from 37 percent to 46 percent, while the share of coal decreased from 31 percent to 26 percent.

Since both the construction and operation of natural gas infrastructure at the provincial level is handled by the private sector, the factors determining the timing and the rate of expansion of natural gas networks are typically associated with the economic viability of costly investments that are required to service provinces with natural gas. For example, the proximity to the main ports operated under the jurisdiction of the central government, the potential size of the market (i.e., the number of housing and commercial units or the population size), weather conditions such as the average duration of the heating season, and the conditions of the geographical terrain appear to be important factors (Aras and Aras, 2005; Cesur et al., 2016). Accordingly, it is no surprise that provinces such as Istanbul, Ankara, Bursa, and Eskisehir, that are either highly populated, located within close proximity to main pipelines, or with long and cold winters are among the early adopters, and provinces in remote regions with difficult access (e.g., Hakkari and Sirnak) or mild climates (e.g., Antalya, Aydin, and Mersin) are either late adopters or with no natural gas access yet. ${ }^{11}$

\section{Data}

Measures of Natural Gas

\footnotetext{
${ }^{11}$ Once a province is connected to a natural gas network, the decision about whether to switch from coal to natural gas depends on the type of housing unit occupied by the household. For example, the decision is voluntary for single family residential units. For residential buildings with multiple housing units, in which over 80 percent of all households reside, a simple majority decision among the residential units is required to make the change from coal to natural gas.
} 
Data on natural gas have been obtained from the Turkish Natural Gas Journal (for the period 2001 to 2012) and the Turkish Energy Market Regulatory Authority (for years 2013 and 2014). ${ }^{12}$ We construct measures that capture the deployment of natural gas networks both in the intensive and extensive margins. For the extensive margin, we create an indicator variable for whether natural gas networks are present and functioning in a province in each year between 2001 and 2014, and for the intensive margin we create an intensity measure representing the utilization rate of natural gas as measured by the number of individual subscribers per 100 persons. $^{13}$

There is considerable variation in both extensive and intensive dimensions of deployment of natural gas. For example, only 5 of the 81 Turkish provinces had access to a natural gas network in 2001, but this figure has grown to 71 in $2014 .{ }^{14}$ During the period of our analysis, the natural gas intensity has grown from 3.8 to 14.1 percent. However, the rate of expansion varies widely across provinces. For example, the subscription rate for natural gas services is over 30 percent in Ankara, Eskisehir, and Istanbul, suggesting that the coverage is near universal if one assumes between three to four individuals living per household. ${ }^{15}$ But then Antalya - a province located on the Mediterranean coast with a warm climate - has a natural gas intensity of only 0.75 percent despite having a network in place since 2009.

\footnotetext{
${ }^{12}$ The Natural Gas Journal is published in Turkish under the name "Dogal Gaz Dergisi” and available at http://www.dogalgaz.com.tr/. It provides data on natural gas on an annual basis until the end of 2012. Note that for the period after 2012 the same data are also available from the Turkish Energy Market Regulatory Authority at http://www.epdk.org.tr/tr/anasayfa.

${ }^{13}$ An alternative approach could be to create the utilization rate per households instead of per persons. However, it is not possible to generate this figure for every year since province level household numbers are only available for 2000 and 2011. Following Cesur et al. (2016), we constructed an approximation to the number of households per province assuming a linear growth rate. Results from the analysis using this variable as the treatment measure did not change any of the implications of the results presented in this paper.

${ }^{14}$ Appendix Table 1 presents the list of provinces with natural gas infrastructure by 2014 along with the year of adoption and natural gas intensity in that year.

${ }^{15}$ The average household size in Turkey is 3.8 according to statistics from the Turkish Statistical Institute. See http://www.tuik.gov.tr/PreHaberBultenleri.do?id=15843.
} 


\section{Measures of Mortality}

The data on mortality were obtained from the Turkish Statistical Institute (TurkStat) for the period between 2001-2014. We created age and gender specific mortality rates defined as the number of deaths per 1,000 persons present in each category. We consider mortality rates for males and females between ages 25 to 54 and ages 55 and older that represent the non-elderly adult and the elderly mortality rates, respectively. ${ }^{16}$ As shown in Table $1 \mathrm{~A}$, the mortality rate averages about one per 1,000 persons among those aged 25-54 and jumps to about 18 per 1,000 for those aged 55 and older. Furthermore, the mortality rate is higher among males than females for both adults and the elderly. Figures in columns 2 to 5 of Table $1 \mathrm{~A}$ reveal that mortality rates differ considerably between provinces with and without a natural gas network. For example, province-year observations with a natural gas network (column 3) has almost twice as high a mortality rate as those without one (column 2) regardless of age category and gender. A similar picture is drawn by columns 4 and 5, which show the means of mortality rates for provinces which did not gain access to a natural gas network at any time during the period of our analysis and those which did gain access to a network during the same period, respectively. The information illustrated in Table 1A may lead one to conclude that mortality rates may be directly related to natural gas. However, this would be misleading since it fails to account for potentially important factors that may be correlated with both the deployment of gas networks and public health at the provincial level. Below we elaborate more on some of the differences between provinces with and without natural gas network.

\footnotetext{
${ }^{16}$ Using alternative age cut-offs to define adult (e.g. 25 to 64) and elderly mortality rates (e.g., 65 and older) did not cause any appreciable changes to our main findings. Although the focus of this paper is adult and the elderly mortality, we also estimated models for infant mortality. The results from the analysis of infant mortality presented in Appendix Table 2, basically provides a reassurance of the findings in Cesur et al. (2016), which performed the same analysis using data for the period between 2001-2011. The results shown in Appendix Table 2 also reveal that there is no difference in the estimated relationship between natural gas and infant mortality between males and females.
} 


\section{Time-variant Provincial Characteristics}

In our analysis, we account for a set of time-variant characteristics at the provincial level. These characteristics include number of hospitals and hospital beds per 100,000 persons, number of automobiles per 1,000 persons, number of physicians per 100,000 persons, an indicator variable for whether the province has a Family Physician Program in place, and an indicator variable for whether the elected mayor of the central district of the associated province has the same political affiliation with the political party governing Turkey. ${ }^{17}$ We also account for differences in income per capita, unemployment rate, percentage of population holding a high school degree, percentage of population holding a college degree, and number of pupils per teacher in secondary schools at the sub-regional level. ${ }^{18}$ The information pertaining to presence of the Family Physician Program comes from the Ministry of Health, while all other control variables are obtained from the TurkStat. ${ }^{19}$ We also construct dummy variables that equal unity for observations with missing data on the explanatory variables.

Table 1B displays the means and standard deviations for these characteristics for the full sample as well as by breakdowns of the presence of a natural gas network. As shown in the table, provinces with and without a natural gas network differ from each other in a number of dimensions. For example, provinces with access to a natural gas network also have more

\footnotetext{
${ }^{17}$ Data on province populations are obtained from the TurkStat for years 2000 and 2007-2014 and from the Turkish Ministry of Health between 2001 and 2006. Since no Census was conducted between years 2001 and 2006, the province populations for the period of 2001-2006 are based on extrapolations implemented by the Ministry of Health. Alternatively, we imputed the population figures between 2001 and 2006 using province-specific growth rates. Using these values produce results that are nearly identical to those presented in this paper. These results are available from the authors upon request.

${ }^{18}$ These variables are only available at the sub-regional level. According to the TurkStat, Turkey is classified into 12 regions, 26 sub-regions, and 81 provinces. These regions and sub-regions are made up of clusters of provinces that are grouped together based on geographical proximity to each other and for statistical purposes.

${ }^{19}$ The Family Physician Program in Turkey, which was introduced in 2005, has extended basic healthcare services to the entire Turkish population under a free-of-charge and single-payer system that is fully financed and administered by the central government. Cesur et al. (2015) show that the program led to significant improvements in public health.
} 
automobiles, higher income, a larger number of hospital beds and physicians, better educated populations, and a higher likelihood of having a Family Physician Program in place. These differences suggest that natural gas expansion is more likely in provinces that are wealthier, more urban, and with more educated populations. This is not surprising because the timing and intensity of deployment of a natural gas network may be positively associated with demand for natural gas services, which, in turn, is likely to be positively influenced by all these factors. Finally, provinces with natural gas are more likely to have a central district mayor who is affiliated with the ruling party. Again, this should not come as a surprise in a country where the decisions over resource allocation for local investment projects are controlled by the central government.

\section{Econometric Approach}

\section{Natural Gas and Air Pollution}

In order for the deployment of natural gas networks to influence mortality, the displacement of natural gas by coal induced by these networks should lead to an improvement in air quality. There is already evidence, albeit descriptive, in support of a negative relationship between the expansion of the natural gas infrastructure and air pollution (Kaygusuz, 2007). In order to fortify this assumption with more concrete evidence and also to set the stage for our main analysis, we obtained data on province level yearly averages of particulate matter $\left(\mathrm{PM}_{10}\right)$ and sulfur dioxide $\left(\mathrm{SO}_{2}\right)$ from the Turkish Ministry of Health. ${ }^{20}$ Then, we run regressions for each of these measures on natural gas intensity controlling for a vector of province characteristics along with province fixed effects, and region specific year dummies. The point

\footnotetext{
${ }^{20}$ Air pollution is measured by the provincial meteorology centres. The measurements are taken for a minimum of 21 days for each month for at least nine months.
} 
estimates on the measure of natural gas intensity from these regressions are -0.057 for $\mathrm{PM}_{10}$ (pvalue $<0.05)$ and -0.022 for $\mathrm{SO}_{2}(\mathrm{p}$-value $<0.01)$ suggesting that a one-percentage point increase in the intensity of natural gas results in 5.7 and 2.2 percent decreases in these two pollutants, respectively. ${ }^{21}$ Furthermore, as indicated by p-values in parentheses the estimates are statistically significant at the 5- and 1-percent levels despite the significantly reduced sample sizes. $^{22}$

\section{Natural Gas and Mortality}

In order to investigate the impact of natural gas networks on adult and the elderly mortality, we follow the strategy in Cesur et al. (2016) and begin with estimating models of the form:

$$
\log \left(\mathrm{MR}_{\mathrm{pt}}\right)=\mathrm{X}_{\mathrm{pt}} \beta_{\mathrm{o}}+\beta_{1} \mathrm{NG}_{\mathrm{pt}}+\omega_{\mathrm{p}}+\lambda_{\mathrm{rt}}+\tau_{\mathrm{p}} \mathrm{t}+\tau_{\mathrm{p}} \mathrm{t}^{2}+\varepsilon_{\mathrm{pt}}
$$

where $\mathrm{MR}_{\mathrm{pt}}$ represents one of the mortality outcomes for province $\mathrm{p}$ in year $\mathrm{t} . \mathrm{X}_{\mathrm{pt}}$ is a set of exogenous determinants of mortality described above. The $\mathrm{NG}_{\mathrm{pt}}$ is either a binary indicator for whether the province $\mathrm{p}$ has a natural gas network in place or the intensity of natural gas as measured by the number of subscribers to natural gas services per 100 persons in year t. The number of subscribers is the total number of household and business units with access to natural gas. $^{23}$

\footnotetext{
${ }^{21}$ Note that data on $\mathrm{SO}_{2}$ the $\mathrm{PM}_{10}$ is available only for a subset of the observations between 2001 and 2014 and for an unbalanced panel, which results in sample sizes of 772 and 766 year-province observations for $\mathrm{SO}_{2}$ and $\mathrm{PM}_{10}$, respectively. The coefficients on air pollution measures from a specification with province specific linear trends are imprecisely estimated likely due to reduced sample size.

${ }^{22}$ In the interest of space, we only mention the point estimates on natural gas intensity here, but full results are available from the authors upon request.

${ }^{23}$ Since our unit of analysis is at the provincial level, we are not able to separately identify the private and public health benefits associated with natural gas networks. However, by conducting the analysis at the provincial level, we
} 
The causal interpretation of the coefficient $\beta_{1}$ is complicated due to confounding variables that are likely to be correlated with both the deployment of natural gas networks and mortality. In order to control for the impact of these factors, we rely on the longitudinal nature of our data and incorporate a series of fixed effects into equation (1). Specifically, the $\omega_{\mathrm{p}}$ represents province fixed effects accounting for differences across provinces such as poverty, geographic terrain, and climate conditions, which are likely to remain time-invariant during our analysis period. Similarly, the $\lambda_{\mathrm{rt}}$ is a set of region-by-year fixed effects that would capture annual shocks to mortality at the regional level. ${ }^{24}$ The region-by-year fixed effects would also account for time trends that are common across all provinces within a region. ${ }^{25}$ The specification in equation (1) additionally allows for the trends in mortality rates to differ across provinces by accounting for province-specific linear and quadratic trends. These trends, denoted by the terms, $\tau_{\mathrm{p}} \mathrm{t}$ and $\tau_{\mathrm{p}} \mathrm{t}^{2}$, would capture the influence of difficult-to-measure time-varying differences or pre-existing trends across provinces as well as the differences in the rate of growth in natural gas intensity subsequent to the deployment of a natural gas network (Cesur et al., 2016). ${ }^{26}$ They would

are also able to avoid the difficulty of dealing with the endogeneity of individual decisions to switch from coal to natural gas. In that sense, our estimates should be interpreted as the combined effect of natural gas on those who benefit from improved air quality both privately and publicly (Cesur et al., 2016).

${ }^{24}$ As mentioned previously, regions in Turkey are clusters of provinces grouped together based on considerations of geographical proximity to each other and statistical purposes. There are 12 such regions. Since the province of Istanbul constitutes a region by itself, it is merged with the neighboring West Marmara region for computational simplicity when we constructed the region-by-year fixed effects. However, treating Istanbul as a separate region or dropping it from the sample produces nearly identical results. Note that year fixed effects are redundant once regionby-year fixed effects are included. Therefore, the latter would also gauge nationwide shocks to mortality.

${ }^{25}$ Regions have clusters of provinces, which share common characteristics that are likely to be correlated with mortality. Region-by-year fixed effects would account for these common factors. For example, East Marmara is a region with major urban and industrial provinces like Bursa, and Kocaeli. Furthermore, the heavier industrial activity in these provinces may have spillover effects on all the other provinces within the region that are not necessarily as industrial. For example, Bursa and Kocaeli are linked to each other through highly congested routes of transportation that have to pass through Yalova, a smaller and less urban province within the same region. Therefore, any air pollution, for example caused by the traffic congestion between Bursa and Kocaeli, may also affect the air quality in Yalova. Controlling for region-by-year fixed effects would also mitigate concerns about the aggregate impact of these factors.

${ }^{26}$ This application is similar to the one in Wolfers (2006), who examines the impact of unilateral divorce laws on divorce rates. 
address the concern that changes in the access to natural gas over time might be correlated with broader changes in public-health conditions or convergence across provinces as well (Barreca et al., 2014). Finally, $\varepsilon_{\mathrm{pt}}$ represents a random error term. Standard errors are robust to any form of heteroscedasticity and serial correlation as they are clustered at the province level to allow for correlation within a province (Bertrand et al., 2004).

As mentioned above, equation (1) can be estimated by using either a binary treatment variable for the presence of a natural gas network or a continuous intensity measure, which captures the extent to which natural gas networks are utilized by the public within a province. In the former approach, the coefficient $\beta_{1}$ would measure any permanent shift in the rate of mortality associated with the deployment of a natural gas network averaged over the period in which a province has the network in place. This would be a measure independent of the actual level of the intensity of natural gas utilization in a province. However, the deployment of a natural gas network in a province and the adoption of natural gas by the residents of a province for space heating and cooking purposes are two separate processes. The latter is a process that evolves over time and one that depends on a number of factors including the relative price of coal to natural gas. In the end, it is the actual displacement of coal by natural gas that would have any bearing in terms of influencing public health. Unless the displacement rate of coal by natural gas reaches a critical level that would have an effect on air pollution, a binary treatment model would fail to register any impact on mortality even if all of the provinces have a natural gas network deployed, leading to the misleading conclusion that there is no association between natural gas and mortality. ${ }^{27}$ This problem may be particularly severe in the current context,

\footnotetext{
${ }^{27}$ For instance, consider the extreme case where a province has natural gas available for its citizens as an alternative source of fuel, but nobody utilizes it. In this case, the effect of natural gas utilization on mortality should be zero, but a specification with a binary treatment measure would fail to reveal that.
} 
where there is considerable variation in the intensity of treatment exposure across provinces and over time.

To see this more clearly, in Appendix Table 3 we present estimates of the impact of a binary indicator of natural gas on the rate of mortality using the specification expressed in equation (1). The first column presents the raw correlations between the natural gas indicator and the all age mortality rate (Panel A), mortality rate for those aged 25-54 (Panel B), and mortality rate for those aged 55 and older (Panel C), all in natural logarithms. As shown in the table, all of these correlations are positive and significant, and remain so even after controlling for region-by-year fixed effects. Only after accounting for permanent differences across provinces in column 3 do these estimates become negative as consistent with the notion that the displacement of coal by natural gas triggered by the deployment of natural gas networks had a mortality reducing influence. Moreover, the estimates change little in response to controlling for province specific linear and quadratic trends and time-varying characteristics of provinces. They are also small in size and statistically insignificant in these specifications.

In order to properly capture the dynamic nature of the treatment, we estimate equation (1) using the intensity measure of natural gas utilization. This specification recognizes the fact that the displacement of coal by natural gas is a process that occurs gradually and one that cannot be captured using a binary treatment model. The intensity specification is also more relevant from a public policy perspective when it comes to formulating policies to accomplish targeted levels of utilization of natural gas services. By employing a treatment measure that captures the extent to which natural gas services are deployed in a province, we essentially estimate a dose-effect relationship between natural gas networks and mortality. In this framework, the coefficient $\beta_{1}$ in 
equation (1) using the continuous treatment measure would be interpreted as the impact of the rate of natural gas intensity on mortality.

Identification

There is no evidence to suggest that the rationale for the deployment of natural gas networks was to improve public health by reducing air pollution. Nevertheless, the descriptive statistics highlighted in Tables 1A and 1B clearly indicate that the pattern in which these networks have expanded over time and across provinces has not followed a random pattern either. As mentioned before, the provinces with natural gas networks are more likely to be urban, industrial, and with more motor vehicles per capita. Therefore, these provinces may also have higher mortality despite gaining access to a natural gas network. This can be further demonstrated by a simple analysis in which time-varying characteristics of provinces are regressed on a binary indicator for whether a province has a natural gas network in place. The results from this analysis are shown in Appendix Table 4. As shown in column 1, there are strong correlations between observable province characteristics and the natural gas indicator - a pattern that has already been established in Table 1B. As displayed in column 3 of Appendix Table 4, this pattern persists when we use the intensity measure instead. However, accounting for permanent differences across provinces via fixed effects also causes these differences to become much less nuanced, both in terms of size and statistical significance. Once we further control for confounding factors through province-specific linear and quadratic time trends as well as regionby-year fixed effects, none of the characteristics considered in this analysis are related to either of the natural gas measures (see columns 2 and 4). Importantly, none of the estimates reported in Appendix Table 4 are significant statistically or economically. 
To gain further insights about the association between the deployment of natural gas networks and province characteristics, we next run regressions of the measures of natural gas on jointly specified time-varying factors listed in Table 1B. As shown in Appendix Table 5, the estimates from this analysis lend further support to the notion that any of the association between province characteristics and the pattern in which natural gas networks rolled out over time appears to be exogenous to public health, once we control for year and province fixed effects along with province-specific linear and quadratic trends, and region-by-year fixed effects. This conclusion is also supported by the F-statistics and the corresponding p-values reported at the bottom of columns 2 and 4 of Appendix Table 5, which clearly confirm the joint in-significance of all these characteristics. Taken together, the evidence from Appendix Tables 4 and 5 lends support to the notion that the provincial factors that might be associated with the pattern in which the natural gas networks are deployed become inconsequential once unobserved heterogeneity is accounted for. We interpret this as strong evidence that any remaining variation in the expansion of natural gas networks is plausibly exogenous to mortality outcomes (Cesur et al., 2016).

A relevant question to consider is whether there could be other province level policy developments that might be correlated with the deployment of natural gas networks. Alternatively, the deployment of natural gas networks could be part of a larger basket of investments or development projects implemented at the provincial level. We could not identify any such policy decisions that have been rolled out in conjunction with the deployment of natural gas networks. It is important to remember that the authority to enact laws and execute policies concerning energy and health are under the jurisdiction of the central government in Turkey. Consequently, many of these law changes or policies are implemented in all provinces 
concurrently, and thus are accounted for by year fixed effects. ${ }^{28}$ Furthermore, any differential investments by the central government at the provincial level should be captured by provincespecific linear and quadratic time trends alongside with the indicator variable for whether the district mayor of the province is affiliated with the governing political party. Finally, region-byyear fixed effects would account for region specific unobserved heterogeneity such as any regional investments carried out by the central government in an effort to reduce economic and health disparities among regions.

If our identification strategy is valid, then natural gas networks should not have any impact on mortality in provinces prior to the deployment of these networks. A violation of this condition would suggest that any estimate of the relationship between natural gas networks and mortality may at least partially be spuriously driven by pre-existing differences between provinces with and without a natural gas network. A formal testing of this assumption can be performed by using an event-history analysis, which would enable us to trace out the trends in mortality rates year-by-year for the periods leading up to and following the deployment of a natural gas network (Cesur et al., 2016). In practice, we implement this analysis by augmenting equation (1) to include interactions between each of the year indicators with the binary indicator for the presence of a natural gas network. The event-history estimates from a specification that controls for province and region-by-year fixed effects are displayed in Figure 1 along with 95 percent confidence intervals. As shown in the figure, none of the interaction terms are

\footnotetext{
${ }^{28}$ It can also be argued that natural gas adoption and intensity may influence migration decisions of households between provinces with and without a natural gas infrastructure. The internal migration decisions are primarily determined by economic factors in Turkey and the flow of migration has been from rural to urban provinces in recent decades. To the extent that families migrating into provinces with natural gas are from low socio-economic status, our estimates would be a lower bound. Data on the proportion of migrants by province are available from the TurkStat only for the period 2008-2014. We estimated models of migration as a function of natural gas adoption and expansion along with other control variables. The coefficients on the two natural gas variables were both small and imprecisely estimated, suggesting that migration decisions are unrelated to natural gas. These results are available from the authors upon request.
} 
statistically significantly different from zero in the years prior to deployment of a natural gas network in a province. It is assuring that there is no evidence of any systematic relationship between the treatment and mortality measures in those years. As also illustrated in Figure 1, there is a clear departure towards reduced mortality beginning with one year after the deployment of a natural gas network. Furthermore, the estimates on the interaction terms gradually become more negative over time, which is a pattern consistent with the notion that the presence of a natural gas network makes a difference in mortality only after the utilization of natural gas services becomes widespread enough to have an influence on air quality. In fact, the estimates on the interaction terms reach statistical significance only in the fourth year of deployment. Taken together, the evidence presented in Figure 1 supports the hypothesis that natural gas networks in Turkey had a causal negative effect on mortality.

\section{Results}

Table 2 presents the estimates of the impact of natural gas intensity from equation (1) on measures of mortality. ${ }^{29}$ Panel A shows estimates for all age mortality, while Panels B and C show estimates for those aged 25-54 and 55 and older, respectively. In each panel, the first column displays estimates from a specification with no controls, followed by specifications that successively add region-by-year fixed effects, province fixed effects, linear and quadratic time trends, and time-varying covariates.

The estimates shown in the first column represent raw correlations between natural gas intensity and mortality. As illustrated before, these correlations are positively signed reflecting the non-random nature of the deployment of natural gas networks. Though less pronounced, the

\footnotetext{
${ }^{29}$ We also estimated weighted regressions using the mean population density and birth density as weights. These estimations, shown in Appendix Table 6, did not cause any appreciable changes to the results presented here.
} 
same pattern persists in column 2 of Table 2 when region-by-year fixed effects are added to the specifications. This is also not surprising since region-by-year fixed effects only accounts for time-varying unobservables that are at the national or regional level. It is the pre-existing differences across provinces that are likely to be the source of endogeneity of natural gas networks. Accordingly, when we account for permanent differences across provinces via province fixed effects in column 3, the estimates switch sign and become negative as predicted. In addition to permanent differences, specification in column 3 further accounts for any timevarying differences across provinces that may be trending either linearly or quadratically. As mentioned earlier, these trends are also likely to account for the differences in the rate of increase in natural gas intensity in the post-deployment years of a natural gas network. Doing so causes the estimates on the natural gas intensity to decrease by two to three folds. According to the point estimates, a one-percentage point increase in the natural gas intensity as measured by the number of subscribers to natural gas services per 100 persons would reduce the all age mortality rate by 1.4 percent, the adult mortality rate by 1.9 percent and the elderly mortality rate by 1.2 percent.

It is important to note that controlling observed time-variant characteristics of provinces should not cause any appreciable changes to our estimates if our identification strategy is valid (i.e., the remaining variation in natural gas intensity is exogenous to health outcomes once the unobserved heterogeneity is captured by province fixed effects and province-specific time trends). As displayed in column 5 of Table 2, all three estimates on natural gas intensity remain unchanged. In particular, controlling for the eleven time-varying covariates listed in Table 1B causes no change in the estimates of the impact of natural gas intensity on mortality. 
To put these point estimates into context, we next conduct several back of the envelope calculations for the number of lives saved as a result of the displacement of coal by natural gas. As illustrated in Table 1A, the average mortality rate for all ages in our province-year observations with a natural gas network is 5.18 per 1,000 individuals. Then, a point estimate of 0.014 translates into approximately 0.073 lives saved per every 1,000 persons in response to a one percentage-point increase in the intensity of natural gas. The total number of deaths in Turkey was about 391,000 in 2014. Therefore, approximately 5,460 lives might have been saved, had the intensity of natural gas been one-percentage point higher. Similarly, the approximate numbers of lives saved among the non-elderly adults and the elderly are 0.027 and 0.292 per 1,000 individuals in these age groups, respectively. Taking the total number of deaths in these age groups in 2014 as a base, these figures translate into a total of 846 lives saved among nonelderly adults and 3,851 lives saved among the elderly with respect to a one-percentage point increase in the intensity of natural gas. It is important to recognize that the number of lives saved among the elderly is much higher than that among the adults even though the percentage effect is greater for the adults than the elderly. This is not surprising because individuals aged 55 and older have a much higher baseline mortality and they are also more susceptible to health hazards of air pollution. For example, preexisting cardio-respiratory disorders are more common among the elderly than among the younger age groups.

Our empirical analysis essentially exploits the variation in the rate of displacement of coal by natural gas across provinces and over time. In other words, it is assumed that provinces in which the displacement takes place at a faster pace than other provinces should have mortality rates decreasing more rapidly in comparison to those of other provinces. In fact, this is the reason we refrain from using a binary treatment model as it would fail to capture the true 
variation in natural gas utilization. If our assumption is valid, then we should also observe the impact of natural gas networks on mortality to increase over time as an increasing number of households switch from coal to natural gas. To test this, we estimate the impact of dichotomous indicators of the number of years since the adoption of natural gas network on measures of mortality. These results shown in Appendix Table 7 support the notion of a gradual but intensifying pattern in the hypothesized relationship between natural gas networks and mortality. More specifically, the point estimates, which are usually statistically significant, follow an increasing trend over time, i.e., the mortality gains associated with improved air quality are likely to be increasing over time. This is consistent with the notion that chronic health problems exacerbated by air pollution are not usually reversible easily. Another scenario that is consistent with the pattern obtained in Appendix Table 7 is that air pollution needs to be reduced below certain inflection points before significant mortality gains can be realized.

Finally, we subject the results shown in Table 2 to additional scrutiny by performing two robustness analyses. First, we test whether our results are sensitive to the exclusion of provinces that never gained access to a natural gas network during our analysis period. As shown in Appendix Table 8, estimating the model in equation (1) without these provinces produced estimates that are nearly identical to those in Table 2. Second, we exclude provinces that always had a natural gas network during the time period of our analysis. As presented in Appendix Table 9, these results are also indistinguishable from our main estimates. These analyses confirm that our main results are not driven by the possibility that there is something fundamentally different about those provinces. 


\section{Gender-Specific Analysis}

To investigate the extent to which the relationship between natural gas intensity and mortality is gender-specific, we estimate equation (1) separately for males and females. As shown in Table 3, the evidence from this analysis yields no evidence of a clear distinction in the impact of natural gas intensity on mortality by gender. Focusing on the most comprehensive specification, the estimates are fairly close between males and females for all three age categories. This finding is similar to Chen et al. (2013) which examines the mortality and life expectancy consequences of air pollution using a policy experiment from China. Note that a failure to detect any gender differences in the relationship between natural gas intensity and mortality does not necessarily mean that the number of lives saved as a result of the deployment of natural gas networks is identical between males and females since mortality rates are higher for males than females regardless of age. For example, the point estimates from the analysis of

all age mortality indicate that a one-percentage point increase in the intensity of natural gas results in 0.080 male lives saved per 1,000 males and 0.060 females lives saved per 1,000 females. The corresponding figures are 0.036 males and 0.002 females among those aged 25-54, and 0.607 males and 0.396 for females among those aged 55 and older. Cause-Specific Analysis

Finally, we examine whether mortality effects of natural gas networks differ between deaths linked to cardio-respiratory causes and those linked to non-cardio-respiratory causes. The cause-specific analysis is useful because it is important to understand which health conditions are more responsive to improvements in air quality associated with the displacement of coal by natural gas. This knowledge is particularly helpful for the purpose of an accurate cost-benefit analysis associated with any public policies designed to increase the usage of natural gas 
networks such as a subsidy because the cost of end-of-life care differs greatly across various health conditions. A cause-specific examination would also serve as a valuable specification analysis if the results reveal that estimates are stronger for the type of conditions that are more directly linked to ambient air pollution. A failure to find such a pattern would then cast serious doubts on our identification strategy, suggesting that the deployment of natural networks is correlated with other factors or developments associated with public health.

To answer these questions, we follow Chen et al. (2013) and classify deaths into two groups: cardio-respiratory deaths and non-cardio-respiratory deaths. The information used to categorize deaths into these two groups is obtained from the Causes of Death Statistics Database published by the TurkStat. ${ }^{30}$ These statistics are based on underlying causes of deaths. We use the International Classification of Disease (ICD-10) codes for the evaluation of main cause of each death. The cardio-respiratory deaths are those that are linked to ambient air pollution and include heart disease, stroke, lung cancer, and respiratory illnesses. The non-cardio-respiratory deaths include those causes that are unlikely to be related, at least directly, to air pollution and include other cancers, accidental or violent deaths, various stomach ailments.

The results from this analysis are presented in Table 4. Focusing on the last column in Panel A of the table, the estimate on the impact of natural gas intensity on mortality is negative and statistically significant, suggesting that a one-percent increase in the intensity of natural gas results in a 0.9 percent decrease in cardio-respiratory mortality rate. ${ }^{31}$ The point estimate is statistically significant at the five percent level despite likely measurement error in cause-specific

\footnotetext{
${ }^{30}$ See http://www.tuik.gov.tr/PreTablo.do?alt_id=1083.

${ }^{31}$ The Causes of Death Statistics Database covers all identifiable death cases detected by physicians from all localities including provinces and sub-district centers. In comparison with the all age mortality data used in previous estimations, it is less comprehensive particularly in years prior to 2009 and likely to suffer from measurement error to a larger degree. The smaller magnitude of the estimated effect of natural gas is likely to be due to such measurement error.
} 
death classifications. Furthermore, as expected, the estimates for non-respiratory mortality shown in Panel B fail to reveal any impact of natural gas intensity on these deaths. In particular, the estimate from the most comprehensive specification is -0.004 and statistically indistinguishable from zero. In summary, these findings lend further support to our main hypothesis that the mortality gains caused by natural gas networks are attributable to reduced air pollution.

\section{Conclusions}

In this paper, we examine the casual impact of the expansion of natural gas services for residential and commercial use on adult and elderly mortality in Turkey. The roll-out of natural gas networks has led to a widespread displacement of coal by natural gas as the primary source of fuel in Turkey. Given that natural gas is a much cleaner source of fossil fuel than coal, especially when it comes to concentrations of particulate matter, we assess whether any potential reductions in the carbon intensity in the atmosphere led to improvements in adult and elderly health as measured by their respective rates of mortality. To identify these impacts, we utilize the variation in the timing of deployment and intensity of expansion of natural gas networks across Turkish provinces between 2001 and 2014. Our results indicate that the expansion of natural gas services has led to a significant reduction in the rate of overall mortality as well as both adult and elderly mortality rates. The estimates from our most comprehensive specification indicate that a one-percentage point increase in the rate of subscriptions to natural gas services would cause the mortality rate to decrease by 1.4 percent (5,460 fewer deaths) among all age groups, 1.9 percent (848 fewer deaths) among adults, and 1.2 percent (3,851 fewer deaths) among the elderly. Furthermore, our analysis indicates that the mortality gains for both age groups are primarily 
driven by cardio-respiratory deaths, which are more likely to be due to conditions caused or exacerbated by air pollution, such as pulmonary and systemic inflammation, accelerated atherosclerosis, heart arrhythmias, and pneumonia. Finally, our analysis does not reveal any important gender differences in the estimated relationship between the deployment of natural gas networks and mortality.

Taken together, our results highlight the health benefits of a nationwide transition towards a type of fuel that is gaining popularity due to its abundance, relatively lower cost, and higher efficiency. Due to challenges to getting developing countries to commit to legal obligations and the ineffectiveness of regulations due to poor governance and corruption, any meaningful reductions to carbon consumption in that part of the world, at least in the short-run, would likely come from actions or developments that are voluntary and, more importantly, in the economic interest of these countries. The findings of this paper suggest that the availability of large reserves of natural gas coupled with technological innovations in extraction and transmission in recent years has the potential to cause a real improvement in air quality and result in nontrivial improvements in public health. 


\section{References}

Adgate, J.L., Goldstein, B.D. and McKenzie, L.M., 2014. Potential public health hazards, exposures and health effects from unconventional natural gas development. Environmental Science \& Technology, 48(15), pp.8307-8320.

Abbey, D.E., Nishino, N., McDonnell, W.F., Burchette, R.J., Knutsen, S.F., Lawrence Beeson, W. and Yang, J.X., 1999. Long-term inhalable particles and other air pollutants related to mortality in nonsmokers. American Journal of Respiratory and Critical Care Medicine, 159(2), pp. 373-382.

Anderson, M.L., 2015. As the wind blows: The effects of long-term exposure to air pollution on mortality. NBER Working Paper No. 21578.

Aras, H. and Aras, N., 2005. Eskişehir'de konutsal doğal gaz talebine ekonomik göstergelerin ve dış ortam sıcaklığının etkileri. Mühendis ve Makine Dergisi, 46(540), pp. 20-27.

Barreca, A., Clay, K. and Tarr, J., 2014. Coal, smoke, and death: Bituminous coal and American home heating. NBER Working Paper No. 19881.

Bertrand, M., Duflo, E.and Mullainathan, S., 2004. How much should we trust differences-indifferences estimates? Quarterly Journal of Economics, 119(1), pp. 249-275.

Blamberger, M. and Oswald, R., 2012.Impacts of gas drilling on animal and human health. New Solutions: A Journal of Environmental and Occupational Health, 22(1), pp. 51-77.

Brown, S.P.A., Krupnick, A. and Walls, M.A., 2009. Natural gas: a bridge to a low-carbon future? RFF Issue Brief 09-11, Resources for the Future, Washington, DC.

Center for Climate and Energy Solutions, 2013. Leveraging natural gas to reduce greenhouse gas emissions. http://www.c2es.org/publications/leveraging-natural-gas-reduce-greenhouse-gasemissions.

Cesur, R., Güneş, P.M., Tekin, E. and Ulker, A., 2015. The value of socialized medicine: the impact of universal primary healthcare provision on birth and mortality rates in Turkey. NBER Working Paper No. 21510.

Cesur, R., Tekin, E. and Ulker, A., 2016. Air pollution and infant mortality: Evidence from the expansion of natural gas infrastructure. Economic Journal, doi: 10.1111/ecoj.12285

Chen, R., Kan, H., Chen, B., Huang, W., Bai, Z., Song, G. and Pan, G., 2012. Association of particulate air pollution with daily mortality the China air pollution and health effects study. American Journal of Epidemiology, 175(11), pp. 1173-1181. 
Chen, Y., Ebenstein, A., Greenstone, M. and Li, H., 2013. Evidence on the impact of sustained exposure to air pollution on life expectancy from China's Huai River policy. Proceedings of the National Academy of Sciences, 110(32), pp.12936-12941.

Clougherty, J.E., 2010. A growing role for gender analysis in air pollution epidemiology. Environmental Health Perspectives, 118(2), p.167.

Colborn, T., Kwiatkowski, C., Schultz, K. and Bachran, M., 2012. Natural gas operations from a public health perspective, Human and Ecological Risk Assessment: an International Journal, 17(5), pp. 1039-1056.

Delfino, R.J., Constantinos, S. and Malik, S., 2005. Potential role of ultrafine particles in associations between airborne particle mass and cardiovascular health. Environmental Health Perspectives, 113, pp. 934-946.

Dockery, D.W., Pope, A. and Xu, X., et al., 1993. An association between air pollution and mortality in six US cities. New England Journal of Medicine, 329, pp. 1753-1759.

Englert, N., 2004. Fine particles and human health - a review of epidemiological studies. Toxicology Letters, 149(1), pp.235-242.

Finkel, M.L. and Hays, J., 2015. Environmental and health impacts of 'fracking': why epidemiological studies are necessary. Journal of Epidemiology and Community Health, doi:10.1136/jech-2015-205487.

Finkel, M.L. and Law, A., 2011. The rush to drill for natural gas: a public health cautionary tale. American Journal of Public Health, 101(5), pp.784-785.

Greenstone, M. and Hanna, R., 2014. Environmental regulations, air and water pollution, and infant mortality in India. American Economic Review, 104(10), pp. 3038-72.

Hill, E.L., 2012. Unconventional natural gas development and infant health: evidence from Pennsylvania. Charles H. Dyson School of Applied Economics and Management Working Paper, 12, p.2013.

Howarth, R.W., Ingraffea, A. and Engelder, T., 2011. Natural gas: should fracking stop? Nature, 477(7364), pp. 271-275.

International Energy Agency. 2015. Global coal demand stalls after more than a decade of relentless growth. http://www.iea.org/newsroomandevents/pressreleases/2015/december/globalcoal-demand-stalls-after-more-than-a-decade-of-relentless-growth.html.

Jayachandran, S., 2009. Air quality and early-life mortality: evidence from Indonesia's wildfires. Journal of Human Resources, 44(4), pp. 916-954. 
Kaygusuz, K., 2007. Energy use and air pollution issues in Turkey. CLEAN-Soil, Air, Water, 35(6), pp. 539-547.

Knittel, C.R., Metaxoglou, K. and Trindade, A., 2015. Natural gas prices and coal displacement: Evidence from electricity markets. NBER Working Paper No. 21627.

Krieger N., 2003. Genders, sexes, and health: what are the differences, and why does it matter? International Journal of Epidemiology, 32, pp. 652-657.

Levi, M., 2013. Climate consequences of natural gas as a bridge fuel. Climatic Change, 118(34), pp. 609-623.

Lockwood, A. H., 2012. The Silent Epidemic: Coal and the Hidden Threat to Health. Cambridge: MIT Press.

Moniz, E.J., Jacoby, H.D. and Meggs, A.J.M., et al., 2011. The future of natural gas. Cambridge, MA: Massachusetts Institute of Technology.

Pope, C.A. III, Burnett., R.T. and Thurston, G.D., et al., 2004. Cardiovascular mortality and long-term exposure to particulate air pollution: epidemiological evidence of general pathophysiological pathways of disease. Circulation, 109, pp. 71-77.

Osborn, S.G., Vengosh, A. and Warner, R. and Jackson, R.B., 2011. Methane contamination of drinking water accompanying gas-well drilling and hydraulic fracturing. Proceedings of the National Academy of Sciences, 108, pp. 8172-8176.

Schlenker, W. and Walker, W.R., 2015. Airports, air pollution, and contemporaneous health. The Review of Economic Studies, p.rdv043.

Tuller, D., 2015. As fracking booms, dearth of health risk data remains. Health Affairs, 34(6), pp. 903-906.

U.S. Energy Information Administration. 2016. International Energy Outlook - 2016. http://www.eia.gov/forecasts/ieo/exec_summ.cfm.

Wolfers, J., 2006. Did unilateral divorce laws raise divorce rates? A reconciliation and new results. American Economic Review, 96(5), pp. 1802-1820. 


\section{Figure 1}

\section{Event-History Estimates of the Impact of Any Natural Gas on Mortality Rate}
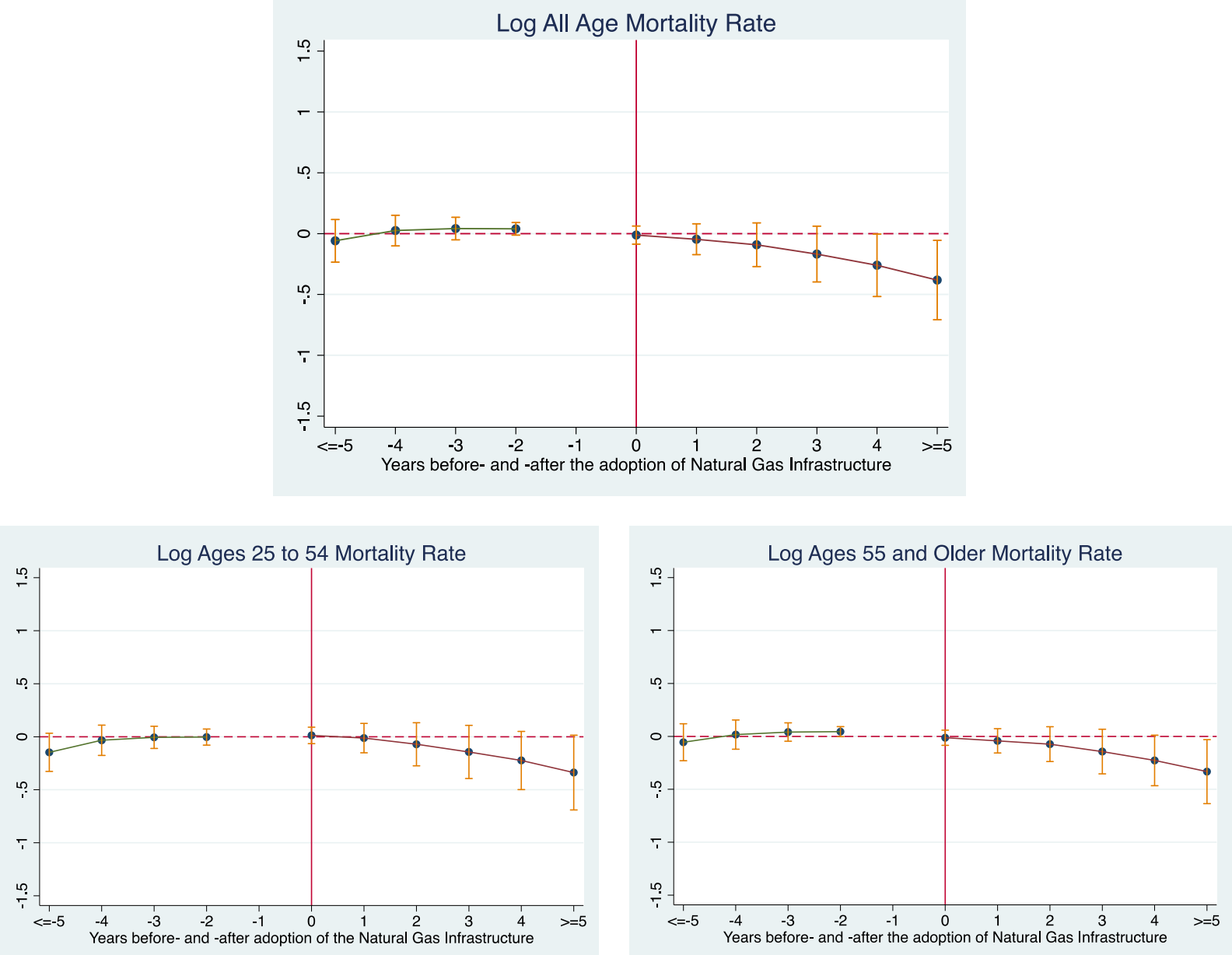

Notes: The figures display coefficients and 95\% confidence intervals. The reference category is one year prior to the deployment of a natural gas network. 
Table 1A

\begin{tabular}{|c|c|c|c|c|c|}
\hline Variable & All & $\begin{array}{c}\text { Any } \\
\text { Natural } \\
\text { Gas }=0\end{array}$ & $\begin{array}{c}\text { Any } \\
\text { Natural } \\
\text { Gas }=1\end{array}$ & $\begin{array}{c}\text { Ever } \\
\text { Natural } \\
\text { Gas }=0\end{array}$ & $\begin{array}{c}\text { Ever } \\
\text { Natural } \\
\text { Gas }=1\end{array}$ \\
\hline Any Natural Gas & $\begin{array}{c}0.44 \\
(0.50)\end{array}$ & $\begin{array}{l}-- \\
--\end{array}$ & $\begin{array}{l}-- \\
--\end{array}$ & $\begin{array}{l}-- \\
--\end{array}$ & $\begin{array}{c}0.51 \\
(0.50)\end{array}$ \\
\hline Natural Gas Intensity & $\begin{array}{c}3.90 \\
(7.07)\end{array}$ & $\begin{array}{l}-- \\
--\end{array}$ & $\begin{array}{c}8.89 \\
(8.33)\end{array}$ & $\begin{array}{l}-- \\
--\end{array}$ & $\begin{array}{c}4.52 \\
(7.42)\end{array}$ \\
\hline All Age Mortality Rate & $\begin{array}{c}3.62 \\
(2.21)\end{array}$ & $\begin{array}{c}2.40 \\
(1.72)\end{array}$ & $\begin{array}{c}5.18 \\
(1.74)\end{array}$ & $\begin{array}{c}2.74 \\
(2.57)\end{array}$ & $\begin{array}{c}3.76 \\
(2.12)\end{array}$ \\
\hline All Age Male Mortality Rate & $\begin{array}{c}3.95 \\
(2.45)\end{array}$ & $\begin{array}{c}2.59 \\
(1.89)\end{array}$ & $\begin{array}{c}5.68 \\
(1.93)\end{array}$ & $\begin{array}{c}2.91 \\
(2.80)\end{array}$ & $\begin{array}{c}4.12 \\
(2.35)\end{array}$ \\
\hline All Age Female Mortality Rate & $\begin{array}{c}3.29 \\
(1.99)\end{array}$ & $\begin{array}{c}2.21 \\
(1.56)\end{array}$ & $\begin{array}{c}4.68 \\
(1.57)\end{array}$ & $\begin{array}{c}2.58 \\
(2.36)\end{array}$ & $\begin{array}{c}3.40 \\
(1.90)\end{array}$ \\
\hline Ages 25 to 54 Mortality Rate & $\begin{array}{c}1.05 \\
(0.58)\end{array}$ & $\begin{array}{c}0.76 \\
(0.53)\end{array}$ & $\begin{array}{c}1.43 \\
(0.39)\end{array}$ & $\begin{array}{c}0.90 \\
(0.73)\end{array}$ & $\begin{array}{c}1.08 \\
(0.55)\end{array}$ \\
\hline Ages 25 to 54 Male 54 Mortality Rate & $\begin{array}{c}1.38 \\
(0.77)\end{array}$ & $\begin{array}{c}0.97 \\
(0.67)\end{array}$ & $\begin{array}{c}1.90 \\
(0.55)\end{array}$ & $\begin{array}{c}1.07 \\
(0.87)\end{array}$ & $\begin{array}{c}1.42 \\
(0.75)\end{array}$ \\
\hline Ages 25 to 54 Female Mortality Rate & $\begin{array}{c}0.72 \\
(0.42)\end{array}$ & $\begin{array}{c}0.55 \\
(0.43)\end{array}$ & $\begin{array}{c}0.94 \\
(0.28)\end{array}$ & $\begin{array}{c}0.71 \\
(0.64)\end{array}$ & $\begin{array}{c}0.72 \\
(0.37)\end{array}$ \\
\hline Ages 55 and Older Mortality Rate & $\begin{array}{l}17.90 \\
(8.86)\end{array}$ & $\begin{array}{l}12.88 \\
(7.66)\end{array}$ & $\begin{array}{l}24.32 \\
(5.54)\end{array}$ & $\begin{array}{c}14.80 \\
(10.95)\end{array}$ & $\begin{array}{l}18.39 \\
(8.39)\end{array}$ \\
\hline Ages 55 and Older Male Mortality Rate & $\begin{array}{c}20.48 \\
(10.17)\end{array}$ & $\begin{array}{l}14.76 \\
(8.80)\end{array}$ & $\begin{array}{l}27.80 \\
(6.44)\end{array}$ & $\begin{array}{c}17.02 \\
(12.37)\end{array}$ & $\begin{array}{l}21.03 \\
(9.68)\end{array}$ \\
\hline Ages 55 and Older Female Mortality Rate & $\begin{array}{l}15.69 \\
(7.79)\end{array}$ & $\begin{array}{l}11.29 \\
(6.77)\end{array}$ & $\begin{array}{l}21.32 \\
(4.84)\end{array}$ & $\begin{array}{l}12.94 \\
(9.84)\end{array}$ & $\begin{array}{l}16.12 \\
(7.33)\end{array}$ \\
\hline Infant Mortality Rate & $\begin{array}{c}8.59 \\
(5.37)\end{array}$ & $\begin{array}{c}6.85 \\
(5.66)\end{array}$ & $\begin{array}{l}10.78 \\
(4.05)\end{array}$ & $\begin{array}{c}7.01 \\
(6.32)\end{array}$ & $\begin{array}{c}8.83 \\
(5.18)\end{array}$ \\
\hline Infant Boy Mortality Rate & $\begin{array}{c}9.32 \\
(5.86)\end{array}$ & $\begin{array}{c}7.51 \\
(6.16)\end{array}$ & $\begin{array}{l}11.57 \\
(4.55)\end{array}$ & $\begin{array}{c}7.30 \\
(6.45)\end{array}$ & $\begin{array}{c}9.63 \\
(5.70)\end{array}$ \\
\hline Infant Girl Mortality Rate & $\begin{array}{c}8.07 \\
(5.06)\end{array}$ & $\begin{array}{c}6.47 \\
(5.34)\end{array}$ & $\begin{array}{l}10.02 \\
(3.90)\end{array}$ & $\begin{array}{c}7.18 \\
(6.57)\end{array}$ & $\begin{array}{c}8.20 \\
(4.79)\end{array}$ \\
\hline Observations & 1134 & 636 & 498 & 154 & 980 \\
\hline
\end{tabular}

Notes: Standard deviations are in parentheses. 
Table 1B

Means of Control Variables by “Any" and "Ever" Natural Gas Status

\begin{tabular}{lccccc}
\hline Variable & All & $\begin{array}{c}\text { Any Natural } \\
\text { Gas }=0\end{array}$ & $\begin{array}{c}\text { Any Natural } \\
\text { Gas }=1\end{array}$ & $\begin{array}{c}\text { Ever Natural } \\
\text { Gas }=0\end{array}$ & $\begin{array}{c}\text { Ever Natural } \\
\text { Gas }=1\end{array}$ \\
\hline Hospitals Per 100K Population & 2.18 & 2.11 & 2.26 & 2.42 & 2.14 \\
& $(0.97)$ & $(1.04)$ & $(0.86)$ & $(1.36)$ & $(0.89)$ \\
Hospital Beds Per 100K Population & 224.17 & 194.43 & 262.17 & 167.85 & 233.03 \\
& $(91.16)$ & $(84.34)$ & $(85.30)$ & $(74.28)$ & $(90.43)$ \\
Physicians Per 100K Population & 122.68 & 100.53 & 150.97 & 84.64 & 128.66 \\
& $(50.97)$ & $(38.60)$ & $(50.88)$ & $(31.78)$ & $(50.85)$ \\
Family Medicine Program & 0.43 & 0.19 & 0.75 & 0.41 & 0.44 \\
& $(0.50)$ & $(0.39)$ & $(0.44)$ & $(0.49)$ & $(0.50)$ \\
Unemployment Rate & 9.82 & 10.21 & 9.49 & 10.14 & 9.76 \\
& $(3.92)$ & $(4.37)$ & $(3.47)$ & $(4.57)$ & $(3.81)$ \\
GDP Per Capita & $8,996.01$ & $7,032.44$ & $1,1576.70$ & $6,121.22$ & $9,447.76$ \\
& $(4,092.08)$ & $(2,861.38)$ & $(4,036.41)$ & $(2,576.44)$ & $(4,103.98)$ \\
Number of Vehicles Per Capita & 0.16 & 0.12 & 0.21 & 0.08 & 0.17 \\
& $(0.09)$ & $(0.07)$ & $(0.07)$ & $(0.05)$ & $(0.08)$ \\
Percent High School & 16.97 & 15.81 & 17.95 & 15.38 & 17.22 \\
& $(4.13)$ & $(3.35)$ & $(4.46)$ & $(3.74)$ & $(4.13)$ \\
Percent College & 7.62 & 5.92 & 9.05 & 5.82 & 7.90 \\
& $(3.19)$ & $(2.26)$ & $(3.17)$ & $(2.74)$ & $(3.17)$ \\
Students Per Teacher & 16.39 & 17.33 & 15.33 & 19.06 & 15.97 \\
Governing Party Mayor & $(4.22)$ & $(4.90)$ & $(2.95)$ & $(6.44)$ & $(3.59)$ \\
& 0.56 & 0.48 & 0.67 & 0.36 & 0.60 \\
Observations & $(0.50)$ & $(0.50)$ & $(0.47)$ & $(0.48)$ & $(0.49)$ \\
\hline
\end{tabular}

Notes: Standard deviations are in parentheses. 
Table 2

The Effect of Natural Gas Intensity on Adult Mortality

$\begin{array}{llll}(1) & (2) & (3) & (4)\end{array}$

(4) (5)

Panel A: Log of All Age Mortality Rate

\begin{tabular}{|c|c|c|c|c|c|}
\hline Natural Gas Intensity & $\begin{array}{c}0.049 * * * \\
(0.008)\end{array}$ & $\begin{array}{c}0.010^{* *} \\
(0.005)\end{array}$ & $\begin{array}{c}-0.038^{* * *} \\
(0.007)\end{array}$ & $\begin{array}{c}-0.014^{* *} \\
(0.006)\end{array}$ & $\begin{array}{c}-0.014^{* * * *} \\
(0.005)\end{array}$ \\
\hline Observations & 1134 & 1134 & 1134 & 1134 & 1134 \\
\hline \multicolumn{6}{|l|}{ Panel B: Log of 25 to 54 Mortality Rate } \\
\hline Natural Gas Intensity & $\begin{array}{c}0.041^{* * *} \\
(0.005)\end{array}$ & $\begin{array}{c}0.013^{* * * *} \\
(0.004)\end{array}$ & $\begin{array}{c}-0.041^{* * * *} \\
(0.008)\end{array}$ & $\begin{array}{c}-0.019 * * * \\
(0.007)\end{array}$ & $\begin{array}{c}-0.019 * * * \\
(0.006)\end{array}$ \\
\hline Observations & 1134 & 1134 & 1134 & 1134 & 1134 \\
\hline \multicolumn{6}{|c|}{ Panel C: Log of 55 and Older Mortality Rate } \\
\hline Natural Gas Intensity & $\begin{array}{c}0.040 * * * \\
(0.005)\end{array}$ & $\begin{array}{c}0.013^{* * *} \\
(0.002)\end{array}$ & $\begin{array}{c}-0.036^{* * *} \\
(0.006)\end{array}$ & $\begin{array}{c}-0.012 * * \\
(0.005)\end{array}$ & $\begin{array}{c}-0.012^{* *} \\
(0.005)\end{array}$ \\
\hline Observations & 1134 & 1134 & 1134 & 1134 & 1134 \\
\hline \multicolumn{6}{|l|}{ Controls For } \\
\hline Region by Year Fixed Effects & No & Yes & Yes & Yes & Yes \\
\hline Province Fixed Effects & No & No & Yes & Yes & Yes \\
\hline Province-specific Linear Trends & No & No & No & Yes & Yes \\
\hline Province-specific Quadratic Trends & No & No & No & Yes & Yes \\
\hline Time-varying Covariates & No & No & No & No & Yes \\
\hline
\end{tabular}

Notes: Robust standard errors, clustered at the province level, are in parentheses. A $*, * *$, or *** indicates significance at the $90 \%, 95 \%$, or $99 \%$ levels, respectively. Time varying covariates include Hospitals Per $100 \mathrm{~K}$ Population, Hospital Beds Per 100K Population, Physicians Per 100K Population, Family Medicine Program, Governing Party Mayor, and Number of Vehicles Per Capita at the province level, as well as Unemployment Rate, GDP Per Capita, Percent High School, Percent College, and Students Per Teacher at the sub-regional level. 
Table 3

The Effect of Natural Gas Intensity on Adult Mortality by Gender

(1) (2) (3) (4)

(5)

Panel A: Log of All Age Mortality Rate

\begin{tabular}{|c|c|c|c|c|c|}
\hline \multirow[b]{2}{*}{ Natural Gas Intensity } & \multicolumn{5}{|c|}{ Males } \\
\hline & $\begin{array}{c}0.050^{* * *} \\
(0.008)\end{array}$ & $\begin{array}{l}0.011^{* *} \\
(0.005)\end{array}$ & $\begin{array}{c}-0.038^{* * *} \\
(0.007)\end{array}$ & $\begin{array}{c}-0.015^{* *} \\
(0.006)\end{array}$ & $\begin{array}{c}-0.014^{* * *} \\
(0.005)\end{array}$ \\
\hline \multirow[b]{2}{*}{ Natural Gas Intensity } & \multicolumn{5}{|c|}{ Females } \\
\hline & $\begin{array}{c}0.048^{* * *} \\
(0.007) \\
\end{array}$ & $\begin{array}{l}0.009 * \\
(0.004) \\
\end{array}$ & $\begin{array}{c}-0.039 * * * \\
(0.007)\end{array}$ & $\begin{array}{c}-0.014^{* *} \\
(0.006) \\
\end{array}$ & $\begin{array}{c}-0.013^{* *} \\
(0.005) \\
\end{array}$ \\
\hline Observations & 1134 & 1134 & 1134 & 1134 & 1134 \\
\hline \multicolumn{6}{|l|}{ Panel B: Log of 25 to 54 Mortality Rate } \\
\hline \multirow[b]{2}{*}{ Natural Gas Intensity } & \multicolumn{5}{|c|}{ Males } \\
\hline & $\begin{array}{c}0.044^{* * *} \\
(0.006) \\
\end{array}$ & $\begin{array}{c}0.013^{* * *} \\
(0.004)\end{array}$ & $\begin{array}{c}-0.041^{* * *} \\
(0.008)\end{array}$ & $\begin{array}{c}-0.019 * * * \\
(0.007)\end{array}$ & $\begin{array}{c}-0.019 * * * \\
(0.006)\end{array}$ \\
\hline \multirow[b]{2}{*}{ Natural Gas Intensity } & \multicolumn{5}{|c|}{ Females } \\
\hline & $\begin{array}{c}0.038^{* * * *} \\
(0.005) \\
\end{array}$ & $\begin{array}{c}0.014^{* * * *} \\
(0.004) \\
\end{array}$ & $\begin{array}{c}-0.043^{* * *} \\
(0.009)\end{array}$ & $\begin{array}{c}-0.019 * * \\
(0.008) \\
\end{array}$ & $\begin{array}{c}-0.019 * * \\
(0.007) \\
\end{array}$ \\
\hline Observations & 1134 & 1134 & 1134 & 1134 & 1134 \\
\hline \multicolumn{6}{|c|}{ Panel C: Log of 55 and Older Mortality Rate } \\
\hline \multirow[b]{2}{*}{ Natural Gas Intensity } & \multicolumn{5}{|c|}{ Males } \\
\hline & $\begin{array}{c}0.040^{* * *} \\
(0.005) \\
\end{array}$ & $\begin{array}{c}0.013^{* * *} \\
(0.002)\end{array}$ & $\begin{array}{c}-0.035^{* * *} \\
(0.006)\end{array}$ & $\begin{array}{c}-0.013^{* *} \\
(0.005) \\
\end{array}$ & $\begin{array}{c}-0.013^{* * *} \\
(0.005) \\
\end{array}$ \\
\hline \multirow[b]{2}{*}{ Natural Gas Intensity } & \multicolumn{5}{|c|}{ Females } \\
\hline & $\begin{array}{c}0.041^{* * * *} \\
(0.005)\end{array}$ & $\begin{array}{c}0.013^{* * *} \\
(0.002)\end{array}$ & $\begin{array}{c}-0.036^{* * *} \\
(0.006)\end{array}$ & $\begin{array}{c}-0.011^{* *} \\
(0.005)\end{array}$ & $\begin{array}{c}-0.011^{* *} \\
(0.005)\end{array}$ \\
\hline Observations & 1134 & 1134 & 1134 & 1134 & 1134 \\
\hline \multicolumn{6}{|l|}{ Controls For } \\
\hline Region-by-year Fixed Effects & No & Yes & Yes & Yes & Yes \\
\hline Province Fixed Effects & No & No & Yes & Yes & Yes \\
\hline Province-specific Linear Trends & No & No & No & Yes & Yes \\
\hline Province-specific Quadratic Trends & No & No & No & Yes & Yes \\
\hline Time-varying Covariates & No & No & No & No & No \\
\hline
\end{tabular}


Table 4

The Effect of Natural Gas Intensity on Mortality by Cause of Death

\begin{tabular}{|c|c|c|c|c|c|}
\hline & (1) & (2) & (3) & (4) & (5) \\
\hline \multicolumn{6}{|c|}{ Panel A: Log of Cardio-respiratory Death Rate } \\
\hline Natural Gas Intensity & $\begin{array}{c}0.044 * * * \\
(0.007)\end{array}$ & $\begin{array}{l}0.010^{*} \\
(0.006)\end{array}$ & $\begin{array}{c}-0.030 * * * \\
(0.006)\end{array}$ & $\begin{array}{c}-0.009 * * \\
(0.005)\end{array}$ & $\begin{array}{c}-0.009 * * \\
(0.004)\end{array}$ \\
\hline Observations & 1134 & 1134 & 1134 & 1134 & 1134 \\
\hline \multicolumn{6}{|c|}{ Panel B: Log of Non-Cardio-respiratory Death Rate } \\
\hline Natural Gas Intensity & $\begin{array}{c}0.073^{* * *} \\
(0.010)\end{array}$ & $\begin{array}{c}0.019 * * * \\
(0.005)\end{array}$ & $\begin{array}{c}-0.021 * * * \\
(0.005)\end{array}$ & $\begin{array}{l}-0.005 \\
(0.004)\end{array}$ & $\begin{array}{l}-0.004 \\
(0.004)\end{array}$ \\
\hline Observations & 1134 & 1134 & 1134 & 1134 & 1134 \\
\hline \multicolumn{6}{|l|}{ Controls For } \\
\hline Region by Year Fixed Effects & No & Yes & Yes & Yes & Yes \\
\hline Province Fixed Effects & No & No & Yes & Yes & Yes \\
\hline Province-specific Linear Trends & No & No & No & Yes & Yes \\
\hline Province-specific Quadratic Trends & No & No & No & Yes & Yes \\
\hline Time-varying Covariates & No & No & No & No & Yes \\
\hline
\end{tabular}

Notes: Robust standard errors, clustered at the province level, are in parentheses. A $*, * *$, or *** indicates significance at the $90 \%, 95 \%$, or $99 \%$ levels, respectively. Time varying covariates include Hospitals Per $100 \mathrm{~K}$ Population, Hospital Beds Per 100K Population, Physicians Per 100K Population, Family Medicine Program, Governing Party Mayor, and Number of Vehicles Per Capita at the province level, as well as Unemployment Rate, GDP Per Capita, Percent High School, Percent College, and Students Per Teacher at the sub-regional level. 


\begin{tabular}{|c|c|c|c|c|c|}
\hline Natural Gas Ado & on Year & $\begin{array}{r}\text { Appendi } \\
\text { ad Natural Gas } \\
\text { Gas Infra }\end{array}$ & $\begin{array}{l}\text { able } 1 \\
\text { tensity in } 2 \\
\text { ucture }\end{array}$ & 4 for Pro & ces with Natu \\
\hline Province & $\begin{array}{c}\text { Adoption } \\
\text { Year }\end{array}$ & $\begin{array}{c}\text { Natural Gas } \\
\text { Intensity in } 2014\end{array}$ & Province & $\begin{array}{l}\text { Adoption } \\
\text { Year }\end{array}$ & $\begin{array}{c}\text { Natural Gas } \\
\text { Intensity in } 2014\end{array}$ \\
\hline Adana & 2010 & 2.03 & Karabuk & 2009 & 17.18 \\
\hline Adiyaman & 2010 & 7.07 & Karaman & 2009 & 12.76 \\
\hline Afyonkarahisar & 2008 & 5.59 & Kars & 2009 & 4.62 \\
\hline Aksaray & 2006 & 11.47 & Kastamonu & 2009 & 7.70 \\
\hline Amasya & 2008 & 13.24 & Kayseri & 2005 & 18.80 \\
\hline Ankara & 1988 & 30.94 & Kilis & 2013 & 2.95 \\
\hline Antalya & 2009 & 0.75 & Kirikkale & 2007 & 20.26 \\
\hline Ardahan & 2014 & 0.83 & Kirklareli & 2009 & 16.27 \\
\hline Aydin & 2012 & 0.83 & Kirsehir & 2007 & 17.69 \\
\hline Balikesir & 2005 & 11.33 & Kocaeli & 1996 & 25.03 \\
\hline Bartin & 2014 & 1.81 & Konya & 2005 & 12.48 \\
\hline Batman & 2012 & 4.02 & Kutahya & 2005 & 14.28 \\
\hline Bayburt & 2009 & 10.97 & Malatya & 2007 & 14.56 \\
\hline Bilecik & 2007 & 19.66 & Manisa & 2007 & 5.78 \\
\hline Bolu & 2010 & 12.65 & Mardin & 2014 & 0.00 \\
\hline Burdur & 2009 & 8.71 & Mersin & 2010 & 1.87 \\
\hline Bursa & 1992 & 25.49 & Mugla & 2014 & 0.02 \\
\hline Canakkale & 2007 & 12.37 & Nevsehir & 2009 & 10.88 \\
\hline Cankiri & 2009 & 11.14 & Nigde & 2007 & 10.74 \\
\hline Corum & 2005 & 15.24 & Ordu & 2009 & 4.81 \\
\hline Denizli & 2007 & 13.15 & Osmaniye & 2011 & 2.47 \\
\hline Diyarbakir & 2009 & 6.97 & Rize & 2009 & 8.13 \\
\hline Duzce & 2006 & 12.44 & Sakarya & 2005 & 14.88 \\
\hline Edirne & 2009 & 9.26 & Samsun & 2006 & 12.01 \\
\hline Elazig & 2009 & 14.85 & Sanliurfa & 2008 & 2.58 \\
\hline Erzincan & 2009 & 12.32 & Siirt & 2012 & 3.86 \\
\hline Erzurum & 2005 & 11.72 & Sivas & 2006 & 14.65 \\
\hline Eskisehir & 1996 & 30.55 & Tekirdag & 2005 & 18.79 \\
\hline Gaziantep & 2008 & 6.09 & Tokat & 2009 & 9.33 \\
\hline Giresun & 2013 & 0.97 & Trabzon & 2010 & 3.42 \\
\hline Gumushane & 2012 & 3.17 & Usak & 2006 & 12.36 \\
\hline Hatay & 2010 & 1.57 & Van & 2008 & 2.91 \\
\hline Isparta & 2009 & 11.72 & Yalova & 2006 & 26.71 \\
\hline Istanbul & 1992 & 30.14 & Yozgat & 2007 & 9.09 \\
\hline Izmir & 2007 & 8.42 & Zonguldak & 2006 & 6.69 \\
\hline Kahramanmaras & 2007 & 6.39 & & & \\
\hline
\end{tabular}

Notes: Provinces without natural gas infrastructure in 2014 are Agri, Artvin, Bingol, Bitlis, Hakkari, Igdir, Mus, Sinop Sirnak, and Tunceli. In Ankara, Bursa, Eskisehir, Istanbul, and Kocaeli natural gas infrastructure was developed prior to 2001. Natural gas intensity is expressed in per hundred populations. 


\section{Appendix Table 2 \\ The Effect of Natural Gas Intensity on Infant Mortality}

\begin{tabular}{|c|c|c|c|c|c|}
\hline & (1) & (2) & (3) & (4) & (5) \\
\hline \multicolumn{6}{|l|}{ Panel A: Total Sample } \\
\hline Natural Gas Intensity & $\begin{array}{c}0.037 * * * \\
(0.005)\end{array}$ & $\begin{array}{c}0.021 * * * \\
(0.006)\end{array}$ & $\begin{array}{c}-0.060 * * * \\
(0.014)\end{array}$ & $\begin{array}{c}-0.029 * * * \\
(0.011)\end{array}$ & $\begin{array}{c}-0.029 * * * \\
(0.010)\end{array}$ \\
\hline Observations & 1122 & 1122 & 1122 & 1122 & 1122 \\
\hline \multicolumn{6}{|l|}{ Panel B: Males } \\
\hline Natural Gas Intensity & $\begin{array}{c}0.035^{* * *} \\
(0.005)\end{array}$ & $\begin{array}{c}0.021^{* * *} \\
(0.005)\end{array}$ & $\begin{array}{c}-0.061 * * * \\
(0.014)\end{array}$ & $\begin{array}{c}-0.027^{* *} \\
(0.011)\end{array}$ & $\begin{array}{c}-0.028 * * * \\
(0.010)\end{array}$ \\
\hline Observations & 1114 & 1114 & 1114 & 1114 & 1114 \\
\hline \multicolumn{6}{|l|}{ Panel C: Females } \\
\hline Natural Gas Intensity & $\begin{array}{c}0.035^{* * *} \\
(0.005) \\
\end{array}$ & $\begin{array}{c}0.022^{* * *} \\
(0.006)\end{array}$ & $\begin{array}{c}-0.065 * * * \\
(0.013) \\
\end{array}$ & $\begin{array}{c}-0.028 * * \\
(0.012) \\
\end{array}$ & $\begin{array}{c}-0.027^{* *} \\
(0.012) \\
\end{array}$ \\
\hline Observations & 1096 & 1096 & 1096 & 1096 & 1096 \\
\hline \multicolumn{6}{|l|}{ Controls For } \\
\hline Region by Year Fixed Effects & No & Yes & Yes & Yes & Yes \\
\hline Province Fixed Effects & No & No & Yes & Yes & Yes \\
\hline Province-specific Linear Trends & No & No & No & Yes & Yes \\
\hline Province-specific Quadratic Trends & No & No & No & Yes & Yes \\
\hline Time-varying Province Characteristics & No & No & No & No & Yes \\
\hline
\end{tabular}

Notes: Robust standard errors, clustered at the province level, are in parentheses. A *,**, or *** indicates significance at the 90\%, 95\%, or 99\% levels, respectively. Time varying covariates include Hospitals Per 100K Population, Hospital Beds Per 100K Population, Physicians Per 100K Population, Family Medicine Program, Governing Party Mayor, and Number of Vehicles Per Capita at the province level, as well as Unemployment Rate, GDP Per Capita, Percent High School, Percent College, and Students Per Teacher at the sub-regional level. 


\section{Appendix Table 3}

The Effect of Any Natural Gas on Adult Mortality

(1)

(2)

(3)

(4)

(5)

Panel A: Log of All Age Mortality Rate

\begin{tabular}{lccccc}
\hline Any Natural Gas & $0.943^{* * *}$ & $0.215^{* * *}$ & -0.086 & -0.064 & -0.069 \\
& $(0.056)$ & $(0.062)$ & $(0.075)$ & $(0.051)$ & $(0.047)$
\end{tabular}

Panel B: Log of 25 to 54 Mortality Rate

\begin{tabular}{lccccc}
\hline Any Natural Gas & $0.812^{* * *}$ & $0.253^{* * *}$ & -0.048 & -0.046 & -0.052 \\
& $(0.047)$ & $(0.066)$ & $(0.082)$ & $(0.059)$ & $(0.056)$ \\
\hline
\end{tabular}

Panel C: Log of 55 and Older Mortality Rate

\begin{tabular}{lccccc}
\hline Any Natural Gas & $\begin{array}{c}0.777^{* * *} \\
(0.040)\end{array}$ & $\begin{array}{c}0.238^{* * *} \\
(0.051)\end{array}$ & $\begin{array}{c}-0.083 \\
(0.069)\end{array}$ & $\begin{array}{c}-0.065 \\
(0.049)\end{array}$ & $\begin{array}{c}-0.068 \\
(0.046)\end{array}$ \\
\hline Observations & 1134 & 1134 & 1134 & 1134 & 1134 \\
\hline Controls For & & & & & \\
$\quad$ Region-by-year Fixed Effects & No & Yes & Yes & Yes & Yes \\
Province Fixed Effects & No & No & Yes & Yes & Yes \\
Province-specific Linear Trends & No & No & No & Yes & Yes \\
Province-specific Quadratic Trends & No & No & No & Yes & Yes \\
Time-varying Province Characteristics & No & No & No & No & Yes \\
\hline
\end{tabular}

Notes: Robust standard errors, clustered at the province level, are in parentheses. A *, **, or *** indicates significance at the $90 \%, 95 \%$, or $99 \%$ levels, respectively. Time varying covariates include Hospitals Per $100 \mathrm{~K}$ Population, Hospital Beds Per 100K Population, Physicians Per 100K Population, Family Medicine Program, Governing Party Mayor, and Number of Vehicles Per Capita at the province level, as well as Unemployment Rate, GDP Per Capita, Percent High School, Percent College, and Students Per Teacher at the sub-regional level. 


\begin{tabular}{|c|c|c|c|c|}
\hline Estimates of Time Varying Obse & $\begin{array}{l}\text { Appendix T } \\
\text { ble Province }\end{array}$ & $\begin{array}{l}\text { ble } 4 \\
\text { haracte }\end{array}$ & s on Natura & Gas Inc \\
\hline & $(1)$ & $(2)$ & (3) & $(4)$ \\
\hline & Any Natı & 1 Gas & Natural Gas & ntensity \\
\hline Dependent Variables & & & & \\
\hline Hospitals Per 100K Population & 0.146 & -0.023 & 0.003 & -0.009 \\
\hline & $(0.116)$ & $(0.061)$ & $(0.009)$ & $(0.009)$ \\
\hline & [1134] & [1134] & [1134] & [1134] \\
\hline Hospital Beds Per 100K Population & $67.740 * * *$ & -1.997 & $4.183^{* * *}$ & -0.312 \\
\hline & $(9.291)$ & $(3.878)$ & $(0.915)$ & $(0.506)$ \\
\hline & [1134] & [1134] & [1134] & [1134] \\
\hline Physicians Per 100K Population & $50.448 * * *$ & 1.494 & $3.810 * * *$ & -0.374 \\
\hline & $(6.542)$ & $(2.127)$ & $(0.776)$ & $(0.287)$ \\
\hline & [1134] & [1134] & [1134] & [1134] \\
\hline Family Medicine Program & $0.553 * * *$ & -0.031 & $0.029 * * *$ & 0.000 \\
\hline & $(0.037)$ & $(0.048)$ & $(0.006)$ & $(0.005)$ \\
\hline & [1134] & [1134] & [1134] & [1134] \\
\hline Unemployment Rate & -0.721 & 0.495 & -0.045 & -0.036 \\
\hline & $(0.452)$ & $(0.411)$ & $(0.034)$ & $(0.029)$ \\
\hline & [891] & [891] & [891] & [891] \\
\hline GDP Per Capita & $4544.263^{* * *}$ & -15.484 & $365.388 * * *$ & -8.099 \\
\hline & $(470.835)$ & $(57.376)$ & $(34.721)$ & (12.956) \\
\hline & [648] & [648] & [648] & [648] \\
\hline Number of Vehicles Per Capita & $0.090 * * *$ & 0.001 & $0.005^{* * *}$ & -0.000 \\
\hline & $(0.008)$ & $(0.002)$ & $(0.001)$ & $(0.000)$ \\
\hline & [1134] & [1134] & [1134] & [1134] \\
\hline Percent High School & $2.147 * * *$ & 0.135 & $0.207 * * *$ & -0.124 \\
\hline & $(0.454)$ & $(0.221)$ & $(0.031)$ & $(0.080)$ \\
\hline & [891] & [891] & [891] & [891] \\
\hline Percent College & $3.129 * * *$ & 0.090 & $0.249 * * *$ & -0.017 \\
\hline & $(0.330)$ & $(0.104)$ & $(0.036)$ & $(0.022)$ \\
\hline & [891] & [891] & [891] & [891] \\
\hline Students Per Teacher & $-1.994 * * *$ & 0.121 & $-0.109 * *$ & 0.025 \\
\hline & $(0.569)$ & $(0.257)$ & $(0.043)$ & $(0.026)$ \\
\hline & [1053] & [1053] & [1053] & [1053] \\
\hline Governing Party Mayor & $0.182 * * *$ & -0.009 & $0.012 * *$ & -0.009 \\
\hline & $(0.054)$ & $(0.080)$ & $(0.005)$ & $(0.006)$ \\
\hline & [1134] & [1134] & [1134] & [1134] \\
\hline Controls for & & & & \\
\hline Region by Year Fixed Effects & No & Yes & No & Yes \\
\hline Province Fixed Effects & No & Yes & No & Yes \\
\hline Province Linear and Quadratic Trends & No & Yes & No & Yes \\
\hline
\end{tabular}




\begin{tabular}{|c|c|c|c|c|}
\hline $\begin{array}{r}\text { Estimates of Natural Gas Indica } \\
\text { Pr }\end{array}$ & $\begin{array}{l}\text { dix Tabl } \\
\text { Jointly } \\
\text { Sharacte }\end{array}$ & $\begin{array}{l}\text { ecified } \\
\text { tics }\end{array}$ & Jarying & ervable \\
\hline & $(1)$ & $(2)$ & $(3)$ & $(4)$ \\
\hline & Any Nat & al Gas & Natural G & ntensity \\
\hline Independent Variables & & & & \\
\hline Hospitals Per 100K Population & $\begin{array}{l}-0.033 \\
(0.024)\end{array}$ & $\begin{array}{l}-0.007 \\
(0.024)\end{array}$ & $\begin{array}{l}-0.260 \\
(0.450)\end{array}$ & $\begin{array}{c}-0.181 \\
(0.230)\end{array}$ \\
\hline Hospital Beds Per 100K Population & $\begin{array}{c}0.000 \\
(0.000)\end{array}$ & $\begin{array}{l}-0.000 \\
(0.001)\end{array}$ & $\begin{array}{l}-0.005 \\
(0.009)\end{array}$ & $\begin{array}{c}0.001 \\
(0.003)\end{array}$ \\
\hline Physicians Per 100K Population & $\begin{array}{c}0.001 * * \\
(0.001)\end{array}$ & $\begin{array}{c}0.001 \\
(0.001)\end{array}$ & $\begin{array}{c}0.042^{* * *} \\
(0.016)\end{array}$ & $\begin{array}{c}-0.009 \\
(0.007)\end{array}$ \\
\hline Family Medicine Program & $\begin{array}{c}0.149 * * * \\
(0.049)\end{array}$ & $\begin{array}{c}-0.041 \\
(0.061)\end{array}$ & $\begin{array}{c}0.055 \\
(0.780)\end{array}$ & $\begin{array}{c}0.070 \\
(0.373)\end{array}$ \\
\hline Unemployment Rate & $\begin{array}{l}-0.004 \\
(0.006)\end{array}$ & $\begin{array}{c}0.003 \\
(0.009)\end{array}$ & $\begin{array}{c}-0.159 * * \\
(0.064)\end{array}$ & $\begin{array}{l}-0.054 \\
(0.038)\end{array}$ \\
\hline GDP Per Capita & $\begin{array}{c}0.000 * * * \\
(0.000)\end{array}$ & $\begin{array}{c}0.000 \\
(0.000)\end{array}$ & $\begin{array}{c}0.001^{* * *} \\
(0.000)\end{array}$ & $\begin{array}{l}-0.000 \\
(0.000)\end{array}$ \\
\hline Number of Vehicles Per Capita & $\begin{array}{c}0.852 * * \\
(0.422)\end{array}$ & $\begin{array}{c}0.943 \\
(1.739)\end{array}$ & $\begin{array}{l}-3.426 \\
(5.668)\end{array}$ & $\begin{array}{c}-10.658 \\
(10.961)\end{array}$ \\
\hline Percent High School & $\begin{array}{l}-0.005 \\
(0.004)\end{array}$ & $\begin{array}{c}0.002 \\
(0.003)\end{array}$ & $\begin{array}{c}0.044 \\
(0.089)\end{array}$ & $\begin{array}{l}-0.049 \\
(0.047)\end{array}$ \\
\hline Percent College & $\begin{array}{c}0.003 \\
(0.009)\end{array}$ & $\begin{array}{c}0.004 \\
(0.008)\end{array}$ & $\begin{array}{c}0.720^{* * * *} \\
(0.193)\end{array}$ & $\begin{array}{c}0.011 \\
(0.064)\end{array}$ \\
\hline Students Per Teacher & $\begin{array}{c}0.012^{* *} \\
(0.006)\end{array}$ & $\begin{array}{c}0.005 \\
(0.006)\end{array}$ & $\begin{array}{c}0.240^{* *} \\
(0.100)\end{array}$ & $\begin{array}{c}0.008 \\
(0.036)\end{array}$ \\
\hline Governing Party Mayor & $\begin{array}{c}0.130 * * * \\
(0.043)\end{array}$ & $\begin{array}{l}-0.002 \\
(0.046)\end{array}$ & $\begin{array}{c}2.259 * * \\
(0.913)\end{array}$ & $\begin{array}{l}-0.291 \\
(0.206)\end{array}$ \\
\hline Observations & 1,134 & 1,134 & 1,134 & 1,134 \\
\hline R-squared & 0.51 & 0.88 & 0.48 & 0.97 \\
\hline F-test & 36.65 & 0.53 & 7.90 & 0.87 \\
\hline F-test P-value & 0.00 & 0.88 & 0.00 & 0.57 \\
\hline Controls for & & & & \\
\hline Region by Year Fixed Effects & No & Yes & No & Yes \\
\hline Province Fixed Effects & No & Yes & No & Yes \\
\hline Province Linear and Quadratic Trends & No & Yes & No & Yes \\
\hline
\end{tabular}

Notes: Robust standard errors, clustered at the province level, are in parentheses. A *, **, or *** indicates significance at the $90 \%, 95 \%$, or $99 \%$ levels, respectively. Each column pertains to a separate regression equation. 
Appendix Table 6

The Effect of Natural Gas Intensity on Mortality, Population Density Weighted Regressions

\begin{tabular}{lcccc}
\hline & $(1)$ & $(2)$ & $(3)$ & $(4)$ \\
\hline & $\begin{array}{c}\text { Log } \\
\text { Infant } \\
\text { Mortality } \\
\text { Rate }\end{array}$ & $\begin{array}{c}\text { Log } \\
\text { All } \\
\text { Age } \\
\text { Mortality } \\
\text { Rate }\end{array}$ & $\begin{array}{c}\text { Log } \\
\text { Ages } \\
\text { Mortality } \\
\text { Rate }\end{array}$ & $\begin{array}{c}\text { Aog } \\
\text { Ages } \\
\text { Older } \\
\text { Mortality } \\
\text { Rate }\end{array}$ \\
\hline & & & & \\
Natural Gas Intensity & & & & \\
& $-0.028^{* * *}$ & $-0.014^{* * *}$ & $-0.018^{* * *}$ & $-0.012^{* *}$ \\
& $(0.010)$ & $(0.005)$ & $(0.006)$ & $(0.005)$ \\
Observations & & & & \\
\hline Controls For & 1,122 & 1,134 & 1,134 & 1,134 \\
Region-by-year Fixed Effects & Yes & Yes & Yes & Yes \\
Province Fixed Effects & Yes & Yes & Yes & Yes \\
Province-specific Linear Trends & Yes & Yes & Yes & Yes \\
Province-specific Quadratic Trends & Yes & Yes & Yes & Yes \\
Time-varying Province Characteristics & Yes & Yes & Yes & Yes \\
\hline
\end{tabular}

Notes: Robust standard errors, clustered at the province level, are in parentheses. A $*, * *$, or *** indicates significance at the $90 \%, 95 \%$, or $99 \%$ levels, respectively. Time varying covariates include Hospitals Per $100 \mathrm{~K}$ Population, Hospital Beds Per 100K Population, Physicians Per 100K Population, Family Medicine Program, Governing Party Mayor, and Number of Vehicles Per Capita at the province level, as well as Unemployment Rate, GDP Per Capita, Percent High School, Percent College, and Students Per Teacher at the sub-regional level. 


\section{The Effect of Years Since Natural Gas Infrastructure Adoption on Mortality}

\begin{tabular}{lcccc}
\hline & $(1)$ & $(2)$ & $(3)$ & $(4)$ \\
& $\begin{array}{c}\text { Log } \\
\text { Infant } \\
\text { Mortality } \\
\text { Rate }\end{array}$ & $\begin{array}{c}\text { Log All } \\
\text { Age } \\
\text { Mortality } \\
\text { Rate }\end{array}$ & $\begin{array}{c}\text { Log Ages } \\
25 \text { to } 54 \\
\text { Mortality } \\
\text { Rate }\end{array}$ & $\begin{array}{c}\text { Log Ages } \\
5 \text { and Older } \\
\text { Mortality } \\
\text { Rate }\end{array}$ \\
\hline Natural Gas Adoption Year & & & & \\
Natural Gas Year 2 & $-0.183^{*}$ & $-0.083^{* *}$ & -0.071 & $-0.081^{* *}$ \\
& $(0.106)$ & $(0.041)$ & $(0.048)$ & $(0.041)$ \\
Natural Gas Year 3 & $-0.241^{*}$ & $-0.118^{*}$ & -0.117 & $-0.119^{*}$ \\
& $(0.123)$ & $(0.060)$ & $(0.073)$ & $(0.063)$ \\
Natural Gas Year 4 & $-0.288^{*}$ & $-0.156^{*}$ & $-0.188^{*}$ & $-0.150^{*}$ \\
& $(0.162)$ & $(0.082)$ & $(0.099)$ & $(0.084)$ \\
Natural Gas Year 5+ & $-0.377^{* *}$ & $-0.180^{*}$ & $-0.234^{* *}$ & $-0.174^{*}$ \\
& $(0.185)$ & $(0.097)$ & $(0.117)$ & $(0.099)$ \\
Observations & $-0.542^{* *}$ & $-0.231^{*}$ & $-0.285^{* *}$ & $-0.227^{*}$ \\
\hline Controls For & $(0.246)$ & $(0.120)$ & $(0.143)$ & $(0.119)$ \\
Region-by-year Fixed Effects & & & & \\
Province Fixed Effects & 1,122 & 1,134 & 1,134 & 1,134 \\
Province-specific Linear Trends & Yes & Yes & Yes & Yes \\
Province-specific Quadratic Trends & Yes & Yes & Yes & Yes \\
Time-varying Covariates & Yes & Yes & Yes & Yes \\
\hline
\end{tabular}

Notes: Robust standard errors, clustered at the province level, are in parentheses. A *, **, or *** indicates significance at the $90 \%, 95 \%$, or $99 \%$ levels, respectively. Time varying covariates include Hospitals Per $100 \mathrm{~K}$ Population, Hospital Beds Per 100K Population, Physicians Per 100K Population, Family Medicine Program, Governing Party Mayor, and Number of Vehicles Per Capita at the province level, as well as Unemployment Rate, GDP Per Capita, Percent High School, Percent College, and Students Per Teacher at the sub-regional level. 
Appendix Table 8

The Effect of Natural Gas Intensity on Adult Mortality, Excluding Provinces that Never Had Natural Gas Infrastructure

\begin{tabular}{|c|c|c|c|c|c|}
\hline & (1) & $(2)$ & (3) & (4) & (5) \\
\hline \multicolumn{6}{|l|}{ Panel A: Log of All Age Mortality Rate } \\
\hline Natural Gas Intensity & $\begin{array}{c}0.044 * * * \\
(0.007)\end{array}$ & $\begin{array}{l}0.009 * \\
(0.005)\end{array}$ & $\begin{array}{c}-0.027 * * * \\
(0.006)\end{array}$ & $\begin{array}{c}-0.010 * * \\
(0.005)\end{array}$ & $\begin{array}{c}-0.010 * * \\
(0.005)\end{array}$ \\
\hline Observations & 980 & 980 & 980 & 980 & 980 \\
\hline \multicolumn{6}{|l|}{ Panel B: Log of 25 to 54 Mortality Rate } \\
\hline Natural Gas Intensity & $\begin{array}{c}0.038 * * * \\
(0.005)\end{array}$ & $\begin{array}{c}0.014^{* * *} \\
(0.004)\end{array}$ & $\begin{array}{c}-0.029 * * * \\
(0.008)\end{array}$ & $\begin{array}{c}-0.014^{* *} \\
(0.006)\end{array}$ & $\begin{array}{c}-0.013^{* *} \\
(0.005)\end{array}$ \\
\hline Observations & 980 & 980 & 980 & 980 & 980 \\
\hline \multicolumn{6}{|c|}{ Panel B: Log of 55 and Older Mortality Rate } \\
\hline Natural Gas Intensity & $\begin{array}{c}0.038 * * * \\
(0.005)\end{array}$ & $\begin{array}{c}0.014^{* * *} \\
(0.002)\end{array}$ & $\begin{array}{c}-0.025^{* * *} \\
(0.006)\end{array}$ & $\begin{array}{c}-0.009 * \\
(0.004)\end{array}$ & $\begin{array}{c}-0.008 * \\
(0.004)\end{array}$ \\
\hline Observations & 980 & 980 & 980 & 980 & 980 \\
\hline \multicolumn{6}{|l|}{ Controls For } \\
\hline Region by Year Fixed Effects & No & Yes & Yes & Yes & Yes \\
\hline Province Fixed Effects & No & No & Yes & Yes & Yes \\
\hline Province-specific Linear Trends & No & No & No & Yes & Yes \\
\hline Province-specific Quadratic Trends & No & No & No & Yes & Yes \\
\hline Time-varying Covariates & No & No & No & No & Yes \\
\hline
\end{tabular}


Appendix Table 9

The Effect of Natural Gas Intensity on Adult Mortality, Excluding Provinces that Always Had Natural Gas Infrastructure

\begin{tabular}{|c|c|c|c|c|c|}
\hline & (1) & $(2)$ & (3) & $(4)$ & $(5)$ \\
\hline \multicolumn{6}{|l|}{ Panel A: Log of All Age Mortality Rate } \\
\hline Natural Gas Intensity & $\begin{array}{c}0.078^{* * *} \\
(0.009)\end{array}$ & $\begin{array}{c}0.008^{* *} \\
(0.004)\end{array}$ & $\begin{array}{c}-0.039 * * * \\
(0.008)\end{array}$ & $\begin{array}{c}-0.013^{* *} \\
(0.006)\end{array}$ & $\begin{array}{c}-0.013^{* *} \\
(0.005)\end{array}$ \\
\hline Observations & 1064 & 1064 & 1064 & 1064 & 1064 \\
\hline \multicolumn{6}{|l|}{ Panel B: Log of 25 to 54 Mortality Rate } \\
\hline Natural Gas Intensity & $\begin{array}{c}0.061^{* * *} \\
(0.007)\end{array}$ & $\begin{array}{c}0.001 \\
(0.002)\end{array}$ & $\begin{array}{c}-0.040^{* * *} \\
(0.009)\end{array}$ & $\begin{array}{c}-0.018^{* *} \\
(0.007)\end{array}$ & $\begin{array}{c}-0.018^{* * *} \\
(0.007)\end{array}$ \\
\hline Observations & 1064 & 1064 & 1064 & 1064 & 1064 \\
\hline \multicolumn{6}{|l|}{ Panel B: Log of 55 and Older Mortality Rate } \\
\hline Natural Gas Intensity & $\begin{array}{c}0.061^{* * *} \\
(0.006)\end{array}$ & $\begin{array}{c}0.006^{* * *} \\
(0.002)\end{array}$ & $\begin{array}{c}-0.035^{* * *} \\
(0.007)\end{array}$ & $\begin{array}{c}-0.013 * * \\
(0.005)\end{array}$ & $\begin{array}{c}-0.012^{* *} \\
(0.005)\end{array}$ \\
\hline Observations & 1064 & 1064 & 1064 & 1064 & 1064 \\
\hline \multicolumn{6}{|l|}{ Controls For } \\
\hline Region by Year Fixed Effects & No & Yes & Yes & Yes & Yes \\
\hline Province Fixed Effects & No & No & Yes & Yes & Yes \\
\hline Province-specific Linear Trends & No & No & No & Yes & Yes \\
\hline Province-specific Quadratic Trends & No & No & No & Yes & Yes \\
\hline Time-varying Province Characteristics & No & No & No & No & Yes \\
\hline
\end{tabular}

